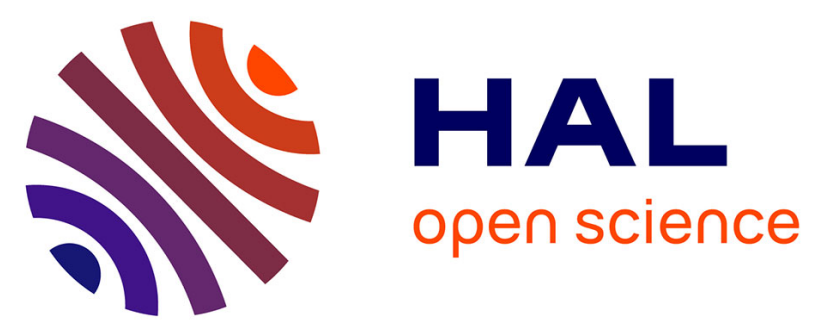

\title{
The pattern of peptides released from dairy and egg proteins is highly dependent on the simulated digestion scenario
}

Amelia Torcello-Gómez, Didier Dupont, Julien Jardin, Valérie Briard-Bion, Amélie Deglaire, Kerstin Risse, Elodie Mechoulan, Alan Mackie

\section{To cite this version:}

Amelia Torcello-Gómez, Didier Dupont, Julien Jardin, Valérie Briard-Bion, Amélie Deglaire, et al.. The pattern of peptides released from dairy and egg proteins is highly dependent on the simulated digestion scenario. Food and Function, 2020, 11 (6), pp.5240-5256. 10.1039/D0FO00744G . hal02648534

\section{HAL Id: hal-02648534 \\ https://hal.inrae.fr/hal-02648534}

Submitted on 29 May 2020

HAL is a multi-disciplinary open access archive for the deposit and dissemination of scientific research documents, whether they are published or not. The documents may come from teaching and research institutions in France or abroad, or from public or private research centers.
L'archive ouverte pluridisciplinaire HAL, est destinée au dépôt et à la diffusion de documents scientifiques de niveau recherche, publiés ou non, émanant des établissements d'enseignement et de recherche français ou étrangers, des laboratoires publics ou privés.

\section{다(1)(2)}

Distributed under a Creative Commons Attribution - ShareAlikel 4.0 International 


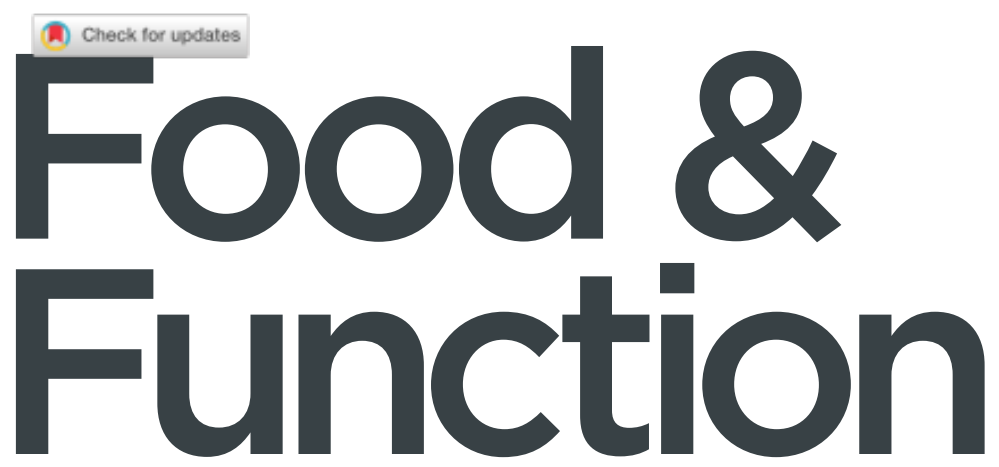

Linking the chemistry and physics of food with health and nutrition

\section{Accepted Manuscript}

This article can be cited before page numbers have been issued, to do this please use: A. TorcelloGomez, D. Dupont, J. Jardin, V. Briard-Bion, A. Deglaire, K. Risse, E. Mechoulan and A. Mackie, Food Funct., 2020, DOI: 10.1039/DOFO00744G.

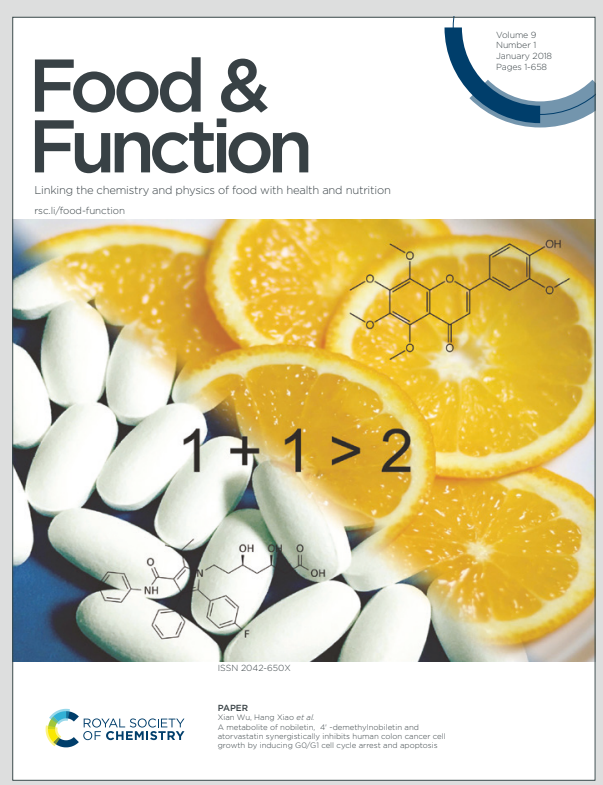

This is an Accepted Manuscript, which has been through the Royal Society of Chemistry peer review process and has been accepted for publication.

Accepted Manuscripts are published online shortly after acceptance, before technical editing, formatting and proof reading. Using this free service, authors can make their results available to the community, in citable form, before we publish the edited article. We will replace this Accepted Manuscript with the edited and formatted Advance Article as soon as it is available.

You can find more information about Accepted Manuscripts in the Information for Authors.

Please note that technical editing may introduce minor changes to the text and/or graphics, which may alter content. The journal's standard Terms \& Conditions and the Ethical guidelines still apply. In no event shall the Royal Society of Chemistry be held responsible for any errors or omissions in this Accepted Manuscript or any consequences arising from the use of any information it contains. 


\title{
The pattern of peptides released from dairy and egg proteins is highly dependent on the simulatied 600074 icline digestion scenario
}

\author{
Amelia Torcello-Gómez, ${ }^{a, *}$ Didier Dupont, ${ }^{b}$ Julien Jardin, ${ }^{b}$ Valérie Briard-Bion, ${ }^{b}$ Amélie Deglaire, ${ }^{b}$ \\ Kerstin Risse, ${ }^{a, c}$ Elodie Mechoulan, ${ }^{a, d}$ and Alan Mackie ${ }^{a}$ \\ ${ }^{a}$ School of Food Science and Nutrition, University of Leeds, Leeds LS2 9JT, UK \\ ${ }^{b}$ INRAE Institut Agro, STLO, 65 Rue St Brieuc, 35042 Rennes, France
}

'Institute of Food Technology and Food Chemistry, Faculty III Process Sciences, Technical University of Berlin, Koenigin-Luise-Str. 22, 14195 Berlin, Germany

${ }^{d}$ Institut Universitaire de Technologie, University of Angers, 4 Boulevard de Lavoisier, 49000 Angers, France

*Corresponding author: M.A.TorcelloGomez@leeds.ac.uk (A. Torcello-Gómez)

\begin{abstract}
Evaluating the gastrointestinal (GI) fate of proteins is part of the assessment to determine whether proteins are safe to consume. In vitro digestion tests are often used for screening purposes in the evaluation of potential allergenicity. However, the current pepsin resistant test used by the European Food Safety Authority, only corresponds to fasted gastric conditions representative of a late phase adult stomach. In addition, these tests are performed on isolated proteins and the effect of the food matrix and processing are not systematically considered. The aim of this research is to compare three different static in vitro Gl scenarios that are physiologically relevant. Namely, an infant, early phase (fed state) adult and late phase (fasted state) adult model. These protocols are applied to well-characterised isolated dairy (6-lactoglobulin and B-casein) and egg (lysozyme and ovalbumin) proteins and the impact of food matrix/processing on their proteolysis is also investigated. A combination of SDS-PAGE, LC-MS/MS and spectrometric assay was used for the evaluation of the proteolysis. Results highlight differences across the three GI scenarios whether on isolated proteins or within food matrices. The infant model led to incomplete digestion, leaving intact egg proteins, either isolated or in the food matrix, and intact 8 -lactoglobulin in the milk. In addition, peptides greater than 9 amino acids were found throughout the intestinal phase for all proteins studied, regardless of the scenario. This reinforces the difficulty of linking protein digestibility to potential allergenicity because many other factors are involved that need further investigation.
\end{abstract}

Keywords: protein, in vitro digestion, food matrix, processing, milk, egg 
40 Evaluating the gastrointestinal (GI) fate of proteins is paramount to assess whether they are safe to consume, including their potential to elicit an allergic reaction. The resistance of proteins to digestion may be significant in relation to determining their allergenic potential since incomplete digestion may cause undesired immune responses via sensitisation and/or elicitation in the duodenum. ${ }^{1}$ Thus, evaluating the digestibility of proteins as part of a suite of assessments and in vitro protocols seems appropriate when ethical constraints hinder in vivo studies. The in vitro digestion model most commonly used for this purpose in line with the European Food Safety Authority (EFSA) guidelines ${ }^{2,3}$ and Implementing Regulation (EU) No 503/2013 (IR503/2013) is the pepsin resistance test. ${ }^{4}, 5$ This mimics the gastric phase of digestion with parameters that are not representative of the normal physiological environment that food is exposed to immediately after consumption. Namely, it uses gastric conditions that are highly acidic and enzyme concentration that would simulate the end of gastric emptying (late phase) or fasted state in human adults. A more realistic approach including a subsequent small intestinal phase and other relevant conditions in healthy adults or in infants may provide useful information on how the combined effect of $\mathrm{pH}$ and enzyme concentration affects protein digestibility. Therefore, in accordance with the guidance offered by the EFSA Genetically Modified Organisms (GMO) panel $^{3}$ this study considers a range of more physiologically relevant conditions that mimic the early phase (or fed state) and late phase (or fasted state) adult and infant GI environments.

The aim of this research is to compare the three in vitro digestion models in the context of assessment of the digestibility of proteins. For this purpose, the comparison uses relevant test proteins that are widely consumed and have previously been characterised to some extent under simulated Gl conditions. In addition, the effect of the food matrix, in which these proteins are naturally present, on their digestibility will be also evaluated with the three models. Thus, the first part of this study comprises the in vitro digestion of isolated proteins from bovine milk (Blactoglobulin, BLG, and B-casein, BCS) and hen's egg (lysozyme, LYS, and ovalbumin, OVA). These proteins are all major allergens varying in stability within the GI tract. BLG and BCS represent two major proteins in bovine milk (allergens Bos d 5 and Bos d 8, respectively) with contrasting susceptibility to GI digestion, stable versus labile. ${ }^{6}$ LYS and OVA (allergens Gal d 4 and Gal d 2, respectively) are major globular proteins in egg white that are moderately resistant to GI digestion. ${ }^{6-}$ ${ }^{8}$ LYS is an enzyme whereas OVA, the most abundant protein in egg white, is a storage protein.

The second part of this study focuses on the in vitro digestion of fresh whole bovine milk and softboiled hen's egg. Both the food matrix and thermal processing effects are taken into account. Pasteurisation is a standard procedure to ensure microbial stability in milk, and eggs are cooked for safe consumption and improved sensory properties. Thermal processing may affect the structure of the natural food matrix, since proteins are partially denatured and conformations are modified, affecting the stability to digestion. ${ }^{9}$ In addition, thermal processing may enhance protein interactions with other components in the food matrix, such as lipids and sugars and can affect the digestion of proteins. ${ }^{10}$ In the current study, the commercial fresh whole milk used was previously pasteurised ( $72{ }^{\circ} \mathrm{C}$ for a minimum of $15 \mathrm{~s}$ ) and homogenised. Homogenisation in milk prior to pasteurisation is also known to affect the ultrastructure by breaking up milk fat globules and changing the interfacial composition from milk fat globule membrane (MFGM) proteins to whey proteins and casein micelles and/or their fragments. ${ }^{11}$ The hen's eggs were soft boiled (boiled individually for $3 \mathrm{~min}$ approximately), as it is very popular in the British breakfast. 


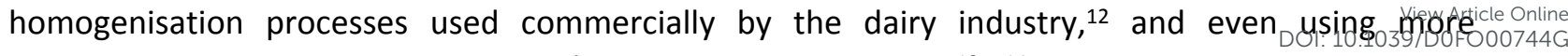
sophisticated in vitro semi-dynamic/dynamic gastric models. ${ }^{13,}{ }^{14}$ Nevertheless, no combined comparison has been made between the digestibility of proteins in milk and the digestibility of isolated proteins, including other human GI conditions. Menard et al. compared the proteolysis kinetics of an infant formula with the infant and early phase adult models mentioned above. ${ }^{15}$ However, no direct comparison with the digestion of isolated proteins was performed. Similarly, Egger et al. recently compared the in vitro static (INFOGEST standardised protocol, i.e. early phase adult) and dynamic digestion of skimmed milk powder proteins with in vivo data. ${ }^{16}$ Their results showed a good agreement between the gastric and intestinal end points of both in vitro models and in vivo data from pigs. Martos et al. assessed the effect of the whole food matrix on egg protein stability to digestion and compared the results with their previous findings on isolated egg proteins. ${ }^{17}$ Nonetheless, they only considered a single adult model of in vitro digestion and the egg was not thermally processed (cooked). The effect of heat treatment on the digestion of egg proteins has been studied on isolated proteins $\left(65^{\circ} \mathrm{C}\right.$ for $30 \mathrm{~min}$ and $90^{\circ} \mathrm{C}$ for $15 \mathrm{~min} ; 80^{\circ} \mathrm{C}$ for $\left.6 \mathrm{~h}\right),{ }^{18-20} \mathrm{egg}$ white $\left(56\right.$ and $65^{\circ} \mathrm{C}$ for $30 \mathrm{~min}$ and $100{ }^{\circ} \mathrm{C}$ for $5 \mathrm{~min} ; 60$ and $80^{\circ} \mathrm{C}$ for $10 \mathrm{~min}$ ) 21,22 and in liquid whole egg (pasteurisation at $60-66^{\circ} \mathrm{C}$ for $\left.4-10 \mathrm{~min}\right)^{23}$ but again only a model of adult digestion was used.

The relationship between allergenicity and stability to digestion of a protein is still controversial due to a lack of knowledge on the exact route of exposure and mechanisms behind food sensitisation and food allergy. ${ }^{1,24}$ For this reason, it is of paramount importance to further investigate the behaviour of known allergens during digestion and identify the products of digestion extensively. In the present study, SDS-PAGE was used to identify intact protein or protein fragments larger than 5 $\mathrm{kDa}$ in digesta samples of isolated proteins and meals. Densitometry analysis of SDS-PAGE allowed the semi-quantification of hydrolysis of intact protein throughout in vitro GI digestion. LC-MS/MS was used to identify protein fragments smaller than $5 \mathrm{kDa}$ in digesta samples of isolated proteins. Only peptides greater than 9 amino acids in length were analysed because of their potential to induce an immune response due to their likelihood of carrying at least two B-cell receptor epitopes. ${ }^{25,}{ }^{26}$ Hydrolysis of total protein in meals was also quantified by measuring the levels of free amine groups with a spectrophotometric assay.

To the best of our knowledge, this is the first time that the in vitro digestion of these meals has been compared under physiologically relevant conditions in infants and adults in two different states: fed versus fasted, and the impact of food matrix/processing assessed by comparison with the digestibility of isolated proteins. The current study highlights differences in protein digestibility across the three Gl scenarios whether on isolated proteins or within food matrices. In addition, peptides greater than 9 amino acids were present throughout the intestinal phase for all proteins, regardless of the model. This emphasises the difficulty of linking digestibility to potential allergenicity because many other factors are involved that need further investigation.

\section{Materials and methods}

All chemicals used were of analytical grade and purchased from Sigma-Aldrich unless otherwise stated.

\subsection{Isolated proteins and meals: source and preparation}

Bovine milk proteins 6 -lactoglobulin (BLG) and B-casein (BCS) were purchased from Merck (Cat. No. L3908 and C6905, respectively) and used as received. The purity reported by the supplier for those particular batches was $\geq 98 \%$ for both proteins. Ovalbumin (OVA) from hen's egg white was purified 


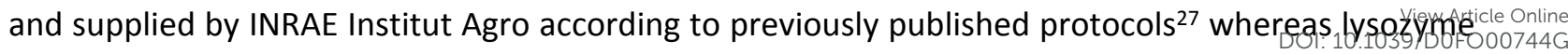
(LYS) was kindly provided by Liot (Liot, Pleumartin, France). The purity of the isolated LYS fraction was $100 \%$ and for OVA fraction was $\geq 85 \%$, as determined by SDS-PAGE, with ovotransferrin being the main contaminant. All of the isolated proteins were prepared by dispersing the lyophilised powder in ultrapure water (Milli-Q) and left under mild stirring for at least $1 \mathrm{~h}$ at room temperature. The protein concentration was set at $5 \mathrm{mg} / \mathrm{mL}$ in order to be consistent with the concentration used for BLG based on that in bovine milk, and on the initial test protein concentration used in the original protocol of the pepsin resistance test. ${ }^{5}$

British fresh whole milk from cow (pasteurised homogenised standardised whole milk) and British large free-range eggs (Class A) were purchased in a local supermarket and stored in the fridge until use before the expiry date. Milk was brought to room temperature before in vitro digestion. Each egg was soft boiled by immersing in boiling tap water ( $700 \mathrm{~mL}$ approximately) for $2 \mathrm{~min}$ and 45 seconds. The soft-boiled egg was cooled in tap water for 1 min and once the shell was removed, the content was mixed well before subjecting to in vitro digestion.

\subsection{In vitro digestion protocols}

An oral phase preceding the gastric phase has not been considered for consistency with the original infant protocol, ${ }^{15}$ and because solutions of isolated proteins and both meals are in liquid/semi-liquid state. In addition, there is no starch present in either meal, therefore the omission of salivary amylase in an oral phase is justified.

All of the models of in vitro digestion comprised a gastric and subsequent intestinal phase. In the gastric phase, the enzyme pepsin (4177 U/mg protein) from porcine gastric mucosa (Cat. No. P7012) was used. In the intestinal phase, individual enzymes trypsin (233 U/mg protein) from porcine pancreas (Cat. No. T0303) and bovine chymotrypsin (55 U/mg protein) (Cat. No. C4129) were used for the intestinal digestion of isolated proteins. The extract pancreatin (6.48 Trypsin U/mg solid) from porcine pancreas (Cat. No. P7545, $8 \times$ USP) was used for the simulated intestinal phase of the meals and infant and early phase models of BLG and BCAS, and the amount added was based on the required trypsin activity in the final mixture. Their activities were determined as described in the electronic supplementary material of Minekus and co-workers. ${ }^{28}$ Bile salts ( $\geq 97 \%$ ) sodium glycocholate (NaGC) and sodium glycochenodeoxycholate (NaGCDC) with Cat. No. G7132 and G0759, respectively, were used in the intestinal phase of isolated proteins. Porcine bile extract (Cat. No. B8631) was used in the intestinal phase of the meals.

In vitro digestion experiments were simulated in $50 \mathrm{~mL}$ conical centrifuge tubes mounted horizontally in a shaking incubator at $37^{\circ} \mathrm{C}$ and $100 \mathrm{rpm}$ for better mixing, and were conducted in triplicate for each model and each protein solution or meal. Control experiments for each model of in vitro digestion were also carried out by replacing the initial volume/weight of protein solution/meal by ultrapure water. Sampling was carried out by collecting aliquots of $200 \mu \mathrm{L}$ at $0.5,2$, $5,10,20,30$ and $60 \mathrm{~min}$ of both gastric and intestinal phase. Proteases were immediately inactivated by adding $5 \mu \mathrm{L}$ of Pepstatin $\mathrm{A}(0.73 \mathrm{mM})$ to gastric samples, or $10 \mu \mathrm{L}$ of $\operatorname{Pefabloc}^{\circledR}(0.1 \mathrm{M})$ to intestinal samples. All samples were frozen at $-20^{\circ} \mathrm{C}$ until further analysis.

\subsubsection{Infant model}

The infant static in vitro digestion protocol originally comprises a gastric and intestinal phase in sequence. ${ }^{15}$ The only adaptation made in the current study was the replacement of bovine bile extract by either porcine bile extract in the digestion of meals, or an equimolar mixture of $\mathrm{NaGC}$ and NaGCDC, which represent the two major forms in human bile, ${ }^{29}$ in the digestion of isolated proteins. 
Briefly, in the gastric phase, $5 \mathrm{~mL}$ of isolated protein $(5 \mathrm{mg} / \mathrm{mL})$ or $5 \mathrm{~g}$ of meal were mixed with irifuandicle Online simulated gastric fluid (SGF) at a ratio protein solution or meal to SGF of 63:37 (v/v). The pH was set to 5.3. The infant SGF comprised $\mathrm{NaCl}(94 \mathrm{mM})$ and $\mathrm{KCl}(13 \mathrm{mM})$, adjusted to $\mathrm{pH} 5.3$ with $1 \mathrm{M} \mathrm{HCl}$. Pepsin activity was $268 \mathrm{U} / \mathrm{mL}$ in the final volume of the gastric chyme. After 60 min of gastric digestion, the $\mathrm{pH}$ was raised to 7 with $1 \mathrm{M} \mathrm{NaOH}$ in order to inactivate pepsin before intestinal digestion.

In the intestinal phase, the gastric chyme was mixed with infant simulated intestinal fluid (SIF) at a ratio of gastric chyme to SIF of $62: 38(\mathrm{v} / \mathrm{v})$ and adjusted to $\mathrm{pH} 6.6$ with $1 \mathrm{M} \mathrm{HCl}$. The infant SIF comprised $\mathrm{NaCl}(164 \mathrm{mM}), \mathrm{KCl}(10 \mathrm{mM})$ and $\mathrm{NaHCO}_{3}(85 \mathrm{mM})$ adjusted to $\mathrm{pH}$ 7. $\mathrm{CaCl}_{2}$ was added separately before starting the intestinal phase at a concentration of $3 \mathrm{mM}$ within the volume of the SIF. The total concentration of bile salts was $3.1 \mathrm{mM}$ in the final volume of the intestinal content. The trypsin activity was $16 \mathrm{U} / \mathrm{mL}$ (also in pancreatin) in the final volume and the chymotrypsin activity was $4 \mathrm{U} / \mathrm{mL}$. This phase lasted for $60 \mathrm{~min}$.

\subsubsection{Early phase adult model}

The early phase adult static in vitro digestion protocol follows the INFOGEST international consensus ${ }^{28}$ with several adaptations. Namely, the oral phase was omitted, the length of gastric and intestinal phases was 60 min each and an equimolar mixture of NaGC and NaGCDC replaced the bile extract for the in vitro digestion of isolated proteins, in order to retain consistency with the infant model. More details of the INFOGEST protocol can be found elsewhere. ${ }^{30}$

Briefly, in the gastric phase, $5 \mathrm{~mL}$ of isolated protein $(5 \mathrm{mg} / \mathrm{mL})$ or $5 \mathrm{~g}$ of meal were mixed with early phase adult SGF at a ratio protein solution or meal to SGF of 50:50 (v/v) and the pH was set to 3 . The early phase adult SGF comprised $\mathrm{NaCl}(47.2 \mathrm{mM}), \mathrm{KCl}(6.9 \mathrm{mM}), \mathrm{KH}_{2} \mathrm{PO}_{4}(0.9 \mathrm{mM}), \mathrm{NaHCO}_{3}(25 \mathrm{mM})$, $\mathrm{MgCl}_{2}\left(\mathrm{H}_{2} \mathrm{O}\right)_{6}(0.1 \mathrm{mM})$, and $\left(\mathrm{NH}_{4}\right)_{2} \mathrm{CO}_{3}(0.5 \mathrm{mM})$ adjusted to $\mathrm{pH} 3$ with $1 \mathrm{M} \mathrm{HCl}$. $\mathrm{CaCl}_{2}$ was added separately before starting the gastric phase at a concentration of $0.075 \mathrm{mM}$ in the final volume of the gastric chyme. Pepsin activity was $2000 \mathrm{U} / \mathrm{mL}$ in the final volume. After 60 min of gastric digestion, the gastric chyme was immediately subjected to the intestinal phase.

In the intestinal phase, the gastric chyme was mixed with early phase adult SIF at a ratio gastric chyme to SIF of $50: 50(\mathrm{v} / \mathrm{v})$ and adjusted to $\mathrm{pH} 7$ with $1 \mathrm{M} \mathrm{NaOH}$. The early phase adult SIF comprised $\mathrm{NaCl}(38.4 \mathrm{mM}), \mathrm{KCl}(6.8 \mathrm{mM}), \mathrm{KH}_{2} \mathrm{PO}_{4}(0.8 \mathrm{mM}), \mathrm{NaHCO}_{3}(85 \mathrm{mM})$, and $\mathrm{MgCl}_{2}\left(\mathrm{H}_{2} \mathrm{O}\right)_{6}(0.33$ $\mathrm{mM})$, adjusted to $\mathrm{pH}$ 7. $\mathrm{CaCl}_{2}$ was added separately before starting the intestinal phase at a concentration of $0.3 \mathrm{mM}$ in the final volume. The total concentration of bile salts was $10 \mathrm{mM}$ in the final volume. The trypsin activity was $100 \mathrm{U} / \mathrm{mL}$ (also in pancreatin) in the final volume and the chymotrypsin activity was $25 \mathrm{U} / \mathrm{mL}$. This phase lasted for $60 \mathrm{~min}$.

\subsubsection{Late phase adult model}

The late phase adult static in vitro digestion protocol comprised a gastric phase as in the pepsin resistance test protocol ${ }^{5}$ followed by the intestinal phase of the adult model above. Briefly, in the gastric phase, $0.5 \mathrm{~mL}$ of isolated protein $(5 \mathrm{mg} / \mathrm{mL})$ or $0.5 \mathrm{~g}$ of meal were mixed with late phase adult SGF at a ratio protein solution or meal to SGF of 5:95 (v/v). The $\mathrm{pH}$ was set to 1.2. The late phase adult SGF comprised $\mathrm{NaCl}(35 \mathrm{mM})$, adjusted to $\mathrm{pH} 1.2$ with $1 \mathrm{M} \mathrm{HCl}$. Pepsin activity was set to 10 $\mathrm{U} / \mu \mathrm{g}$ of test isolated protein, which is equivalent to $2500 \mathrm{U} / \mathrm{mL}$ in the final volume for the gastric phase of meals. After 60 min of gastric digestion, the gastric chyme was immediately subjected to the intestinal phase as in previous section.

\subsection{SDS-PAGE analysis}




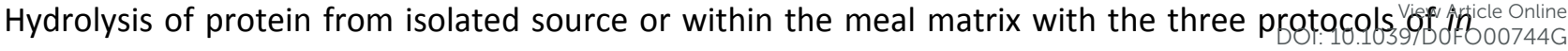
vitro digestion was analysed by sodium dodecyl sulphate polyacrylamide gel electrophoresis (SDSPAGE). This technique allows the identification and semi-quantification of intact protein and protein fragments larger than $5 \mathrm{kDa}$. Precast Bolt 4-12\% Bis-Tris Plus $1 \mathrm{~mm} \times 10$ well gels from Invitrogen were used according to manufacturer's instructions. Digesta samples were diluted with ultrapure water in reducing conditions with dithiothreitol $(0.5 \mathrm{M})$ and with LDS sample buffer $4 \times$ (Invitrogen), followed by heating to $70^{\circ} \mathrm{C}$ for $15 \mathrm{~min}$. Wells were loaded with $1.5 \mu \mathrm{g}$ of isolated protein or $10.5 \mu \mathrm{g}$ of total protein in milk and eggs, taking into account the protein to simulated Gl fluid ratio in order to evaluate the sole impact of the proteolysis. Mark 12 Unstained Standard (Invitrogen) was used as molecular weight marker. Electrophoresis was carried out in MES SDS running buffer (Invitrogen) at $200 \mathrm{~V}$ for $22 \mathrm{~min}$ at room temperature. Gels were fixed in methanol/water/acetic acid (40/50/10 $\mathrm{v} / \mathrm{v}$ ) for $1 \mathrm{~h}$, then rinsed for 5 min three times with ultrapure water and stained with SimplyBlue $\mathrm{e}^{\mathrm{TM}}$ SafeStain (Invitrogen) for $1 \mathrm{~h}$. Distaining was carried out overnight with ultrapure water. Gels were scanned with Bio-Rad ChemiDoc Imager. Densitometry on bands was performed with the software Image Lab ${ }^{\text {TM }} 5.1$ (Bio-Rad). The SDS-PAGE was conducted at least in duplicate for isolated proteins and meals digested in vitro with the three models. Densitometry data are presented as mean values \pm standard deviation. Comparison between in vitro digestion models over time was done with twoway ANOVA and post hoc Bonferroni multiple comparison test with a threshold for significance $p \leq$ 0.05 .

\subsection{LC-MS/MS analysis}

Hydrolysis of isolated proteins with the three in vitro digestion models was analysed by liquid chromatography with tandem mass spectrometry (LC-MS/MS). This technique allows the identification of smaller peptides $(<5 \mathrm{kDa})$. Prior to mass spectrometry analysis, additional Pepstatin was added to all gastric samples. The gastric samples were diluted to the required protein concentration for injection into the spectrometer ( $37 \mathrm{ng}$ of BLG or BCS and $50 \mathrm{ng}$ of LYS or OVA). All gastric samples were filtered using a $0.45 \mu \mathrm{m}$ filter before injection of $10 \mu \mathrm{L}$. For the intestinal samples, $10 \mu \mathrm{L}$ were injected, corresponding to $120 \mathrm{ng}$ of protein (unfiltered) for the infant and early phase adult models and $6 \mathrm{ng}$ of protein (filtered) for the late phase adult model. The smaller amount injected for the latter is a limitation from the highly diluted samples of the late phase adult protocol.

For mass spectrometry analysis, a nano-RSLC Dionex U3000 system fitted to a Q-Exactive mass spectrometer (Thermo Scientific, San Jose, USA) equipped with a nanoelectrospray ion source was used. Samples were concentrated on a $\mu$-precolumn pepMap100 (C18 column, $300 \mu \mathrm{m}$ i.d. $\times 5 \mathrm{~mm}$ length, $5 \mu \mathrm{m}$ particle size, $100 \AA$ A pore size; Dionex, Amsterdam, The Netherlands) and separated on a PepMap RSLC column (C18 column, $75 \mu \mathrm{m}$ i.d. $\times 150 \mathrm{~mm}$ length, $3 \mu \mathrm{m}$ particle size, $100 \AA$ A pore size; Dionex) with a column temperature of $35^{\circ} \mathrm{C}$. Peptide separation was performed at a flow rate of 0.3 $\mu \mathrm{L} / \mathrm{min}$ using solvents $\mathrm{A}[2 \%(\mathrm{v} / \mathrm{v})$ acetonitrile, $0.08 \%(\mathrm{v} / \mathrm{v})$ formic acid and $0.01 \%(\mathrm{v} / \mathrm{v})$ trifluoroacetic acid (TFA) in HPLC grade water] and B [95\% (v/v) acetonitrile, $0.08 \%(\mathrm{v} / \mathrm{v})$ formic acid and $0.01 \%(\mathrm{v} / \mathrm{v})$ TFA in HPLC grade water]. The elution gradient first rose from 5 to $35 \%$ solvent B over 40 min, then up to $85 \%$ solvent $B$ over 5 min before column re-equilibration. The mass spectra were recorded in positive mode using the $\mathrm{m} / \mathrm{z}$ range 350-3000. The resolution of the mass analyser for $\mathrm{m} / \mathrm{z}$ of 200 atomic mass units was set in the acquisition method to 70,000 for MS and 17,500 for MS/MS. For each MS scan, the ten most intense ions were selected for MS/MS fragmentation and excluded from fragmentation for $20 \mathrm{~s}$.

Peptides were identified from the MS/MS spectra using the X!TandemPipeline software (http://pappso.inra.fr) against an in-house database composed of the sequence of the proteins to which was added the common Repository of Adventitious Protein (http://thegpm.org/crap). No 
specific enzymatic cleavage was specified and the possible post-translational modifications searcictrépicle Online were serine phosphorylation, methionine oxidation, and deamidation of glutamine or aspartic acid. Peptides identified with an e-value $<0.01$ were automatically validated, giving an evaluated false discovery rate of less than $1 \%$ at the peptide level. Only peptides of minimum 6 amino acids long can be identified with this strategy.

Data analyses were performed using the R software, version 3.3.1 (R Core Team, 2014). A statistical analysis of the identified peptides longer than 9 amino acids was performed. Peptides of molecular weight $(\mathrm{Mw})$ higher than $4 \mathrm{kDa}$ were not detected automatically by the technique.

\subsection{OPA assay}

The standard ortho-phthaldialdehyde (OPA) spectrophotometric assay ${ }^{31}$ was performed to quantify the amount of free $\mathrm{NH}_{2}$ groups released during the proteolysis of both meals with the three in vitro models. This is indicative of the hydrolysis of total protein. Prior to the assay, $5 \%$ trichloroacetic acid $(166 \mu \mathrm{L})$ was added to digested sample $(100 \mu \mathrm{L})$ to cause the precipitation of insoluble protein that could interfere in the analysis, followed by centrifugation at $10,000 \mathrm{~g}$ for $30 \mathrm{~min}$ at room temperature. OPA reagent was prepared by dissolving $3.81 \mathrm{~g}$ of sodium tetraborate in approximately $80 \mathrm{~mL}$ Milli-Q water under stirring at $50^{\circ} \mathrm{C}$. Then, $0.088 \mathrm{~g}$ dithiothreitol and $0.1 \mathrm{~g}$ sodium dodecyl sulphate were added after cooling down to room temperature. Finally, $0.080 \mathrm{~g}$ OPA dissolved in 2 $\mathrm{mL}$ of ethanol was added in the solution that was made up to $100 \mathrm{~mL}$ with Milli-Q water. L-leucine was used as standard. The calibration curve was obtained with different concentrations (0-10 mM) of the standard solution made in $10 \mathrm{mM}$ phosphate buffer solution. In micro-titre plates, $10 \mu \mathrm{l}$ of standard/sample were loaded into each well and mixed with $200 \mu \mathrm{l}$ of OPA reagent, allowing the reaction to proceed for $15 \mathrm{~min}$ at room temperature. The absorbance was measured at $340 \mathrm{~nm}$ using a microplate photometer (Multiskan FC, ThermoFisher Scientific). Each measurement was conducted in triplicate. Data are presented as mean values \pm standard deviation. Comparison between in vitro digestion models over time was done with two-way ANOVA and post hoc Bonferroni multiple comparison test with a threshold for significance $p \leq 0.05$.

\section{Results and discussion}

Three in vitro digestion protocols have been applied to isolated proteins from bovine milk and hen's egg as well as the respective meal. The infant model follows the protocol recently published by Menard and co-workers, ${ }^{15}$ which is based on in vivo data available in literature, and represents the mildest digestive conditions tested. In particular, the infant gastric average $\mathrm{pH}(5.3)$ is higher than that in adults ( 3 in the early phase and 1.2 in the late phase) and is out of the optimum range for pepsin activity $(\mathrm{pH}=1.6-4)$. Furthermore, the average enzyme activity in the gastric and intestinal compartment is also lower in the infant model, as is the total concentration of bile acids in the small intestine. The early phase adult simulation is based on the INFOGEST harmonised protocol from Minekus and co-workers ${ }^{28}$ that has been validated against in vivo data and its reproducibility has been confirmed by ring trial. ${ }^{32}$ The late phase adult gastric model follows the current pepsin resistance test, ${ }^{5}$ which uses a low $\mathrm{pH}$ and high pepsin activity compared to the early phase adult model. This is followed by the intestinal phase of the INFOGEST harmonised protocol.

\subsection{In vitro digestion of isolated bovine milk proteins}

The digestion of isolated milk proteins, BLG and BCS, was first evaluated with SDS-PAGE and the results for the three in vitro models are shown in Figure $1 A$ and $1 B$. The lanes "BLG" and "BCS" 
correspond to the protein before digestion and the time points of the gastric and intestinal phiass are given in minutes. The control lanes " $\mathrm{C}$ " in both gastric and intestinal phase correspond to the experiment where the isolated protein was replaced by ultrapure water, thus only show bands of the digestive enzymes as labelled in the figure. Top pictures (Figure 1 A1, A2, B1, B2) correspond to the infant model, middle pictures (Figure 1 A3, A4, B3, B4) to the early phase adult model and bottom pictures (Figure 1 A5, A6, B5, B6) to the late phase adult model.

There are clear differences in the gastric proteolysis of BLG and BCS across the three in vitro models. Namely, the whey protein BLG is pepsin-resistant throughout the gastric phase (Figure 1 A1, A3, A5), whereas BCS is rapidly hydrolysed (Figure 1 B1, B3, B5). The band corresponding to intact BLG (18.4 $\mathrm{kDa}$ ) is present after 60 min of gastric digestion regardless of the model and no bands of smaller $\mathrm{Mw}$ corresponding to hydrolysis products can be visualised. This agrees with the results of pepsin resistance test for BLG (or gastric late phase adult model) reported by Thomas and co-workers. ${ }^{5}$ Conversely, the band corresponding to intact BCS $(23.8 \mathrm{kDa})$ disappears at different rates depending on the model and is no longer visible after $60 \mathrm{~min}$ of infant gastric digestion. This is more accurately shown in the percentage of intact protein determined from densitometry analysis on bands (Figure $1 C$ and $1 E$ ). The contrasting susceptibility of BLG and BCS to pepsin digestion is well-known and is related with the nature of both proteins, globular versus open structured, respectively. In particular, most of the pepsin cleavage sites are buried in the hydrophobic core of BLG. ${ }^{33}$

As BCS is susceptible to pepsin, different gastric digestion is expected for this protein across the three models. It is worth noting that in the late phase adult model, the pepsin to test protein ratio is the greatest of the three protocols of in vitro digestion (10000 U/mg of test protein), followed by the early phase adult model ( $800 \mathrm{U} / \mathrm{mg}$ of test protein) and the infant model ( $85 \mathrm{U} / \mathrm{mg}$ of test protein). For this reason, the intensity of the band corresponding to pepsin $(34.6 \mathrm{kDa})$ is greater in the late phase adult model than in the early phase adult model and essentially invisible in the infant model. Therefore, the limited proteolysis of BCS was observed for the infant protocol, followed by intermediate and extensive hydrolysis for the early and late phase adult models, respectively. In the infant model (Figure 1 B1), BCS was partially hydrolysed by pepsin after $30 \mathrm{~s}$ and bands of lower Mw, 4-22 kDa peptides, corresponding to hydrolysis products, are already visible and become more intense at $10 \mathrm{~min}$. Their intensity gradually decreases afterwards, although these peptides are still visible at $60 \mathrm{~min}$ of the gastric phase. In the early phase adult model (Figure 1 B3), only bands corresponding to protein fragments smaller than $20 \mathrm{kDa}$ are visible after $30 \mathrm{~s}$ of gastric digestion and peptides smaller than $5 \mathrm{kDa}$ are detected afterwards, which gradually decrease in intensity until the end of the gastric phase. Figure $1 \mathrm{E}$ also shows a faster disappearance (at $30 \mathrm{~s}$ ) of intact BCS during the gastric phase for the early phase adult model, as compared to the infant one. As discussed by Menard and co-workers, ${ }^{15}$ the slower kinetics of BCS gastric digestion in the infant model is largely due to the loss of pepsin activity at $\mathrm{pH} 5.3, \sim 10 \%$ of its activity at $\mathrm{pH} 2,{ }^{34}$ as compared to the optimal pepsin activity at $\mathrm{pH} 3$ in the early phase adult model, rather than the content of pepsin. Indeed, a previous study reported similar BCS gastric digestibility for an infant and adult model working with similar differences in pepsin content (8-fold lower in the infant) but closer $\mathrm{pH}$ values ( 2.5 and 3 for adult and infant, respectively). ${ }^{6}$ The gastric proteolysis of BCS is even faster for the late phase adult model and only a faint band corresponding to protein fragments of $5 \mathrm{kDa}$ approximately is observed after $30 \mathrm{~s}$ of gastric digestion, and this is not visually detectable after 5 min (Figure 1 B5). This greater extent of BCS hydrolysis in terms of peptides is not visible in the percentage of intact BCS in the gastric phase of both adult models (Figure 1E). 


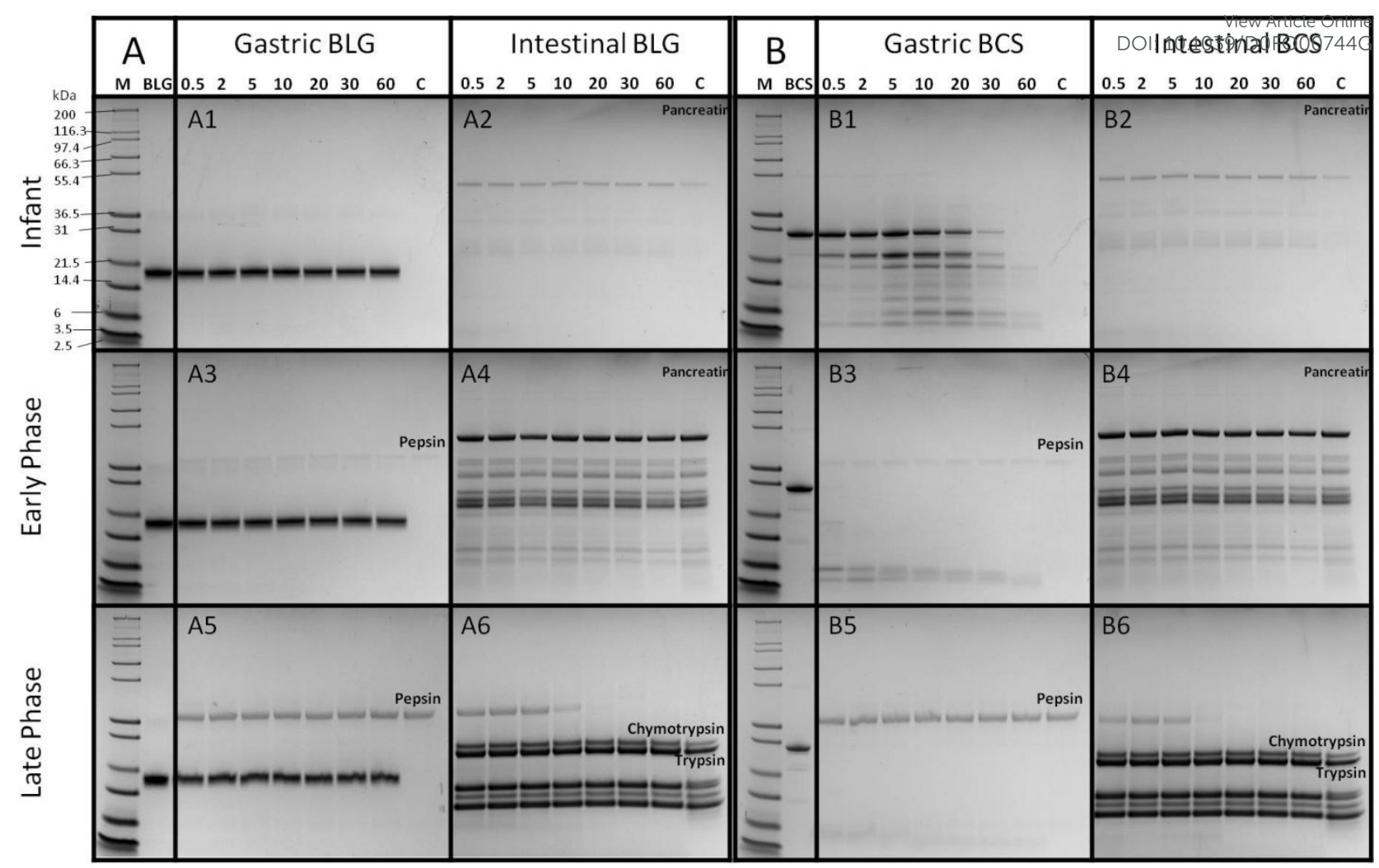

C) Gastric BLG

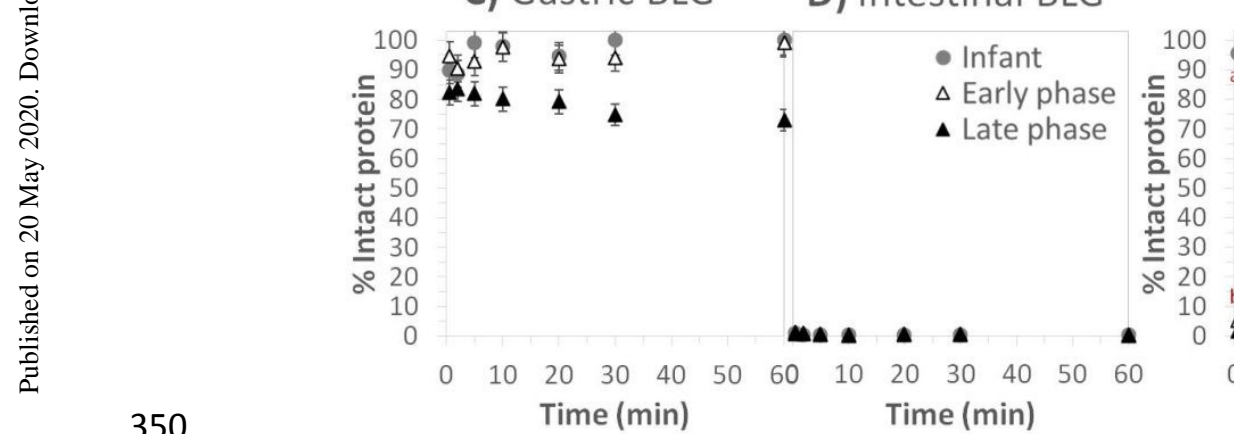

E) Gastric BCS E)

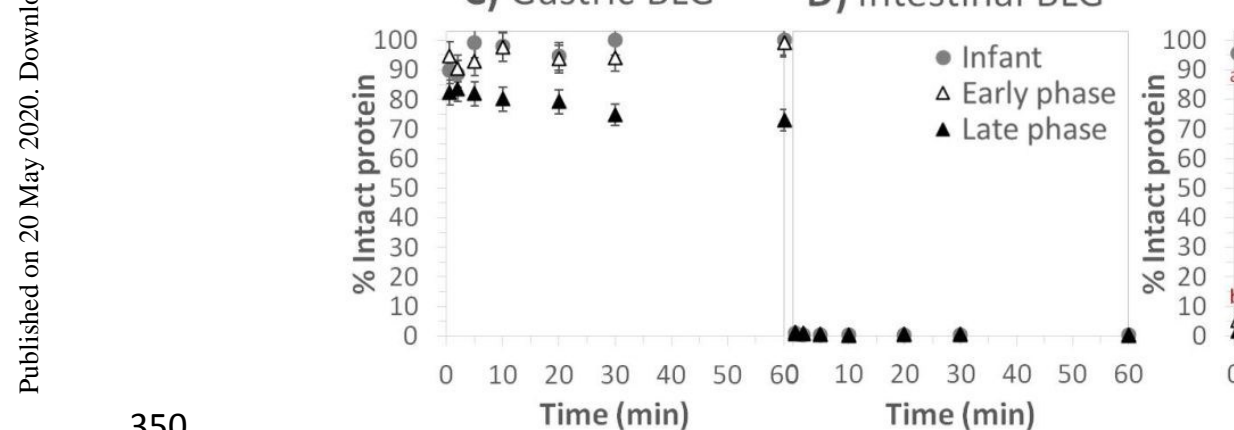

Figure 1: SDS-PAGE of the digesta of isolated BLG (A) and BCS (B) with the infant, early phase adult and late phase adult models. The numbers at the top of the lanes represent the time in min of the gastric or intestinal phase. The M lane corresponds to the Mw marker. BLG and BCS lanes are the protein blank and the $C$ lane is the control of the digestive enzymes. Percentage of intact protein $C$ ), D) BLG and E), F) BCS within the gastric or intestinal phase determined from densitometry on SDSPAGE $(n \geq 2)$. Different letters mean significant differences $(p \leq 0.05)$ between models over time. Absence of letters means no significant differences.

A different story is observed in the intestinal phase, where BLG was significantly hydrolysed even under the milder conditions of the infant model (Figure $1 \mathrm{~A} 2$ ). This agrees with the rapid intestinal digestion of BLG present in infant formula. ${ }^{15} \mathrm{~A}$ very faint band of $\sim 3 \mathrm{kDa}$ appears after $30 \mathrm{~s}$ of intestinal digestion, which gradually vanishes afterwards suggesting almost complete hydrolysis by intestinal proteases (see also Figure 1D). BCS seems to be fully digested after $30 \mathrm{~s}$ of intestinal digestion (Figure 1 B2 and F) although it was already largely hydrolysed by the end of the gastric 
pancreatin extract. In the early phase adult model (Figure 1 A4, B4), the SDS-PAGE suggestsvifhaticle Online both proteins seem to be completely digested after $30 \mathrm{~s}$ of intestinal digestion (see also Figure 1D and 1 F). A faster duodenal digestion is expected since the intestinal enzymes to test protein ratio is also larger in the early phase adult model (68.8 trypsin $\mathrm{U} / \mathrm{mg}$ test protein) as compared to the infant model (6.75 trypsin $\mathrm{U} / \mathrm{mg}$ test protein). This is reflected in the greater intensity of the bands corresponding to pancreatin enzymes. Dupont and co-workers reported much slower kinetics and lower extent of hydrolysis of BLG with an infant and adult intestinal digestion as compared to our results. ${ }^{6}$ This could be partially explained by the use of phospholipids vesicles in their study, which is known to protect BLG against pancreatic proteases degradation. ${ }^{35}$ More importantly, the trypsin/chymotrypsin to test protein ratio used in the present protocols are higher. Regarding the intestinal phase in the late phase adult model, Takagi and co-workers also reported the rapid digestion of BLG under intestinal conditions that would correspond to the late phase adult model in the current study, although without previous gastric digestion. ${ }^{36}$ The bands shown in the intestinal phase of the late phase adult model correspond to trypsin and chymotrypsin (Figure 1 A6, B6). These individual enzymes replaced the pancreatin extract in the remaining digestion experiments on isolated proteins because the greater intensity of the bands corresponding to the complex mixture of enzymes in pancreatin makes difficult the interpretation of the SDS-PAGE results.

The size of the peptides successfully identified by LC-MS/MS in at least two of the three replicates from BLG and BCS digestion at each time point is presented in Figure 2. The number of peptide sequences identified in total for each model of digestion is summarised in Table 1 . The data in the box plots indicate the peptides in the gastric phase from BLG (Figure 2a) were much smaller $(<3$ $\mathrm{kDa})$ than those observed from BCS $(\leq 4 \mathrm{kDa})$ (Figure $2 \mathrm{~b})$. Despite the fact that SDS-PAGE showed that BLG was largely unaffected by pepsin, regardless of the digestion model (Figure $1 \mathrm{~A}$ and $1 \mathrm{C}$ ), the LC-MS/MS data demonstrate that a relatively large number of different peptides (72 in total from the three models) were still detected (Table 1) but were most likely in low abundance. Only a small proportion of BLG was hydrolysed by pepsin during the gastric phase, showing no difference in the band intensity of the intact protein on SDS-PAGE gels for the infant and early phase adult models. However, approximately $20 \%$ of intact BLG was hydrolysed in the late phase adult model as seen in Figure $1 \mathrm{C}$ and a larger number of gastric peptides (53) was also identified in this model, compared to those in the early phase (42) and infant model (32) (Table1). For BLG, the median Mw values are quite similar in the gastric phase between the early and the late phase adult model, with median values decreasing slightly over time. The infant model led to peptides of higher $\mathrm{Mw}$ also decreasing over time. In the late phase adult model, pepsin was able to release rather larger peptides of $2.8 \mathrm{kDa}$ whereas the highest $\mathrm{Mw}$ observed with the early phase model was around $2.1 \mathrm{kDa}$. In the intestinal phase, BLG generated peptides with Mw tending to be higher than in the gastric phase. This can be explained by a much larger proportion of the protein being hydrolysed (Figure 1A and 1D) leading to more diversity in the peptides released. With the infant and early phase adult models, peptide $\mathrm{Mw}$ tended to decrease over digestion time whereas the opposite tendency was seen with the late phase adult model. The low number of peptides identified in the late phase adult intestinal samples (Table 1) could be the result of the smaller amount injected compared to the infant and early phase adult models. In summary, a total of 72 unique peptides were identified in the gastric phase after in vitro digestion of BLG with the three models and 138 in the intestinal phase (Table 1). The larger number of peptides identified in the intestinal phase as compared to the gastric phase positively correlates with a greater extent of proteolysis. 


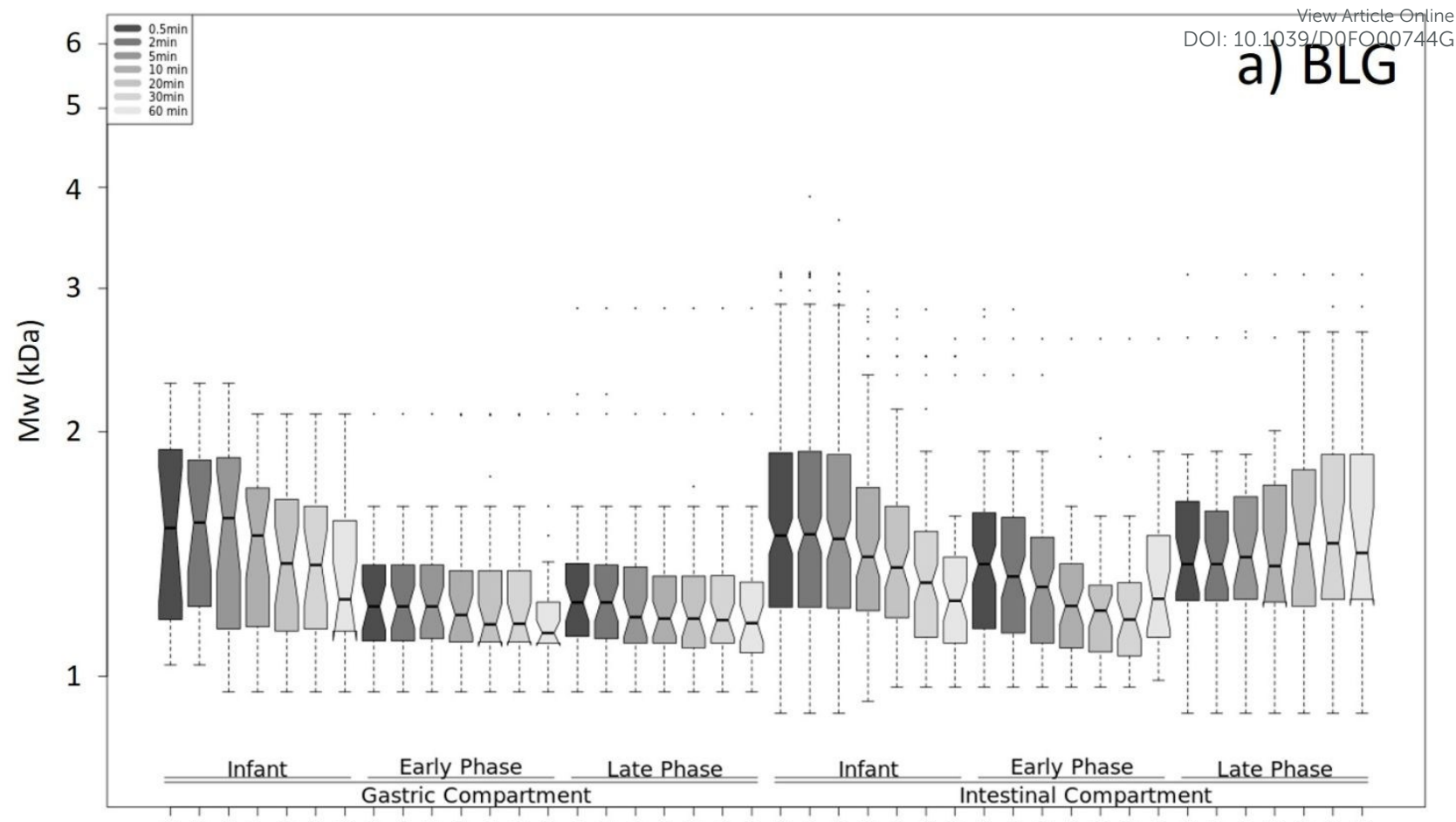

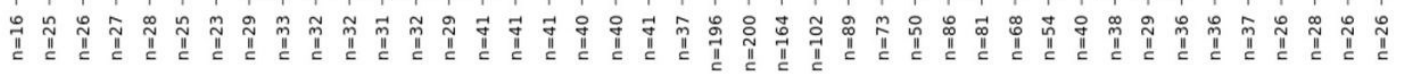

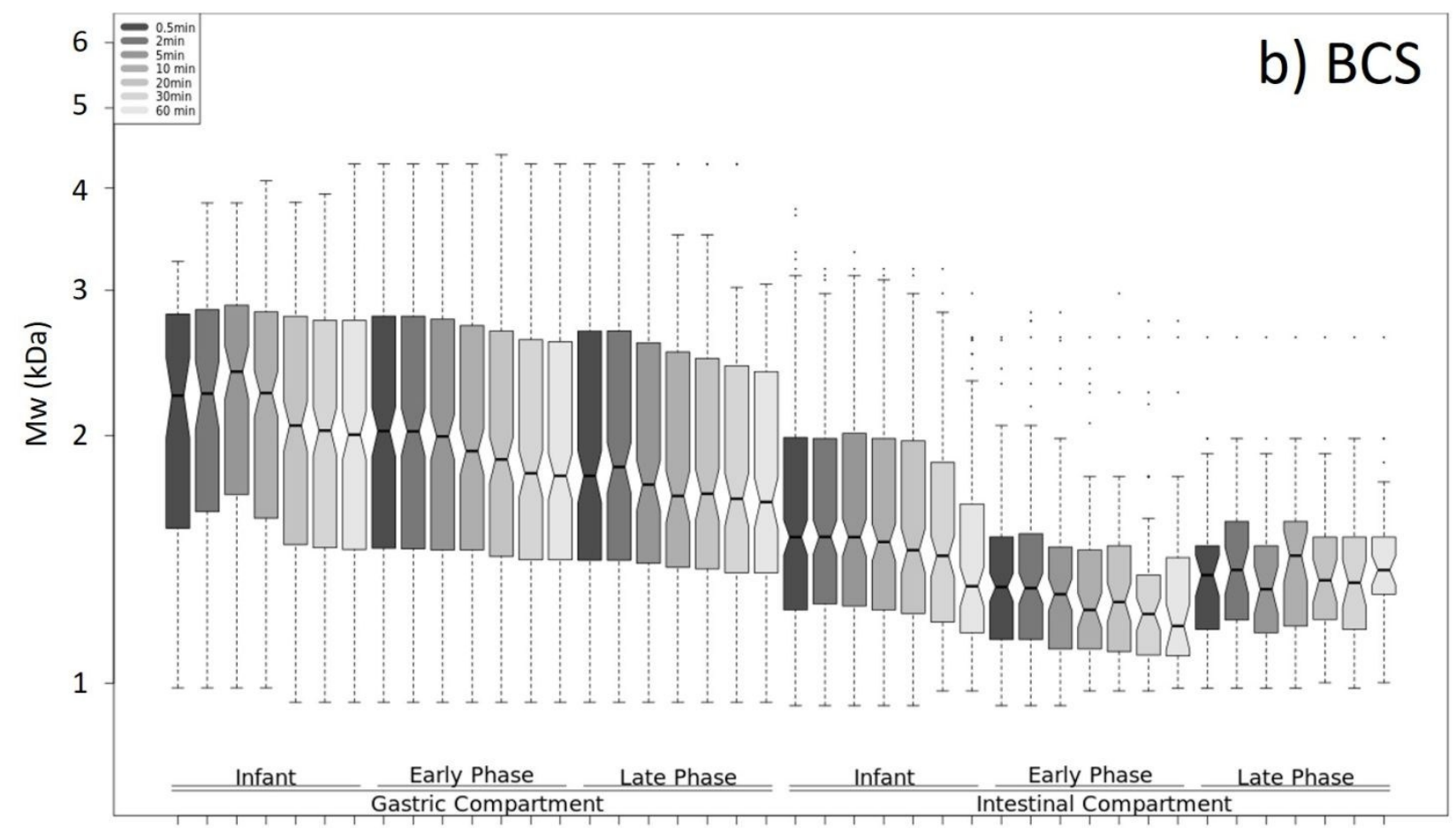

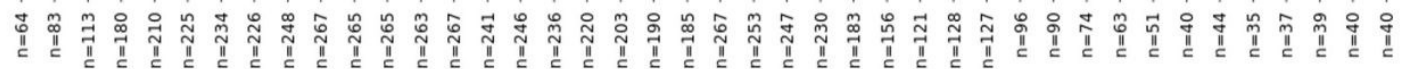

Figure 2: A box plot of peptide molecular weight from BLG (a) and BCS (b) after gastric and intestinal digestion with the three in vitro models. Numbers at the bottom are the number of unique peptide sequences identified at each time point. phase, whereas only 296 were found in the intestinal phase (Table 1). The fact that BCS generated a 


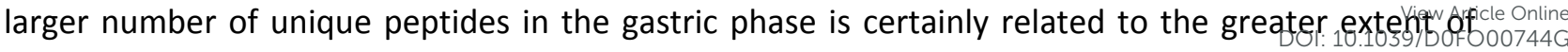
hydrolysis by pepsin (Figure 1B and $1 \mathrm{E}$ ). In the gastric phase, the median values of the peptide Mw observed with the infant model are higher than those in the early phase adult model, which in turn are higher than those in the late phase adult model (Figure $2 \mathrm{~b}$ ). This confirms a more intense proteolysis in the adult models and in particular with the late phase. There is a tendency of the median $\mathrm{Mw}$ value to decrease over time regardless of the in vitro digestion model. In the intestinal phase, median $\mathrm{Mw}$ values were much lower than those for the gastric phase, indicating further extent of hydrolysis into smaller peptides and in agreement with SDS-PAGE results in terms of protein fragments of $\mathrm{Mw}$ smaller than $5 \mathrm{kDa}$ (Figure 1B). Among the three protocols, the infant model led to peptides with highest $\mathrm{Mw}$ as expected. With the infant and early phase adult model, median Mw value decreased consistently over time, which was not the case with the late phase adult model.

In general, the total number of unique peptides identified in the gastric phase increases in the order infant < early phase $\leq$ late phase for BLG and BCS and the opposite is observed in the intestinal phase (Table 1). There may be a positive correlation between the number of unique peptides identified in every digestion product and their in vitro digestibility in the gastric compartment.

Table 1: Summary of the total number of unique peptide sequences identified for the gastric and intestinal phase of each in vitro digestion model and unambiguously with the three models.

\begin{tabular}{|l|l|l|r|r|r|}
\hline Protein & Compartment & $\begin{array}{l}\text { Total from the three } \\
\text { models }\end{array}$ & Infant & $\begin{array}{l}\text { Early } \\
\text { Phase }\end{array}$ & \multicolumn{1}{l|l}{$\begin{array}{l}\text { Late } \\
\text { Phase }\end{array}$} \\
\hline \multirow{2}{*}{ BLG } & Gastric & 72 & 32 & 42 & 53 \\
\cline { 2 - 7 } & Intestinal & 138 & 136 & 63 & 40 \\
\hline \multirow{2}{*}{ BCS } & Gastric & 472 & 224 & 292 & 264 \\
\cline { 2 - 7 } & Intestinal & 296 & 170 & 99 & 40 \\
\hline \multirow{2}{*}{ LYS } & Gastric & 16 & 4 & 3 & 16 \\
\cline { 2 - 7 } & Intestinal & 20 & 20 & 17 & 7 \\
\hline \multirow{2}{*}{ OVA } & Gastric & 91 & 36 & 88 & 85 \\
\cline { 2 - 7 } & Intestinal & 434 & 406 & 286 & 163 \\
\hline
\end{tabular}

\subsection{In vitro digestion of isolated hen's egg proteins}

The proteolysis of isolated egg proteins, LYS and OVA, were first analysed by SDS-PAGE and the results are shown in Figure $3 \mathrm{~A}$ and $3 \mathrm{~B}$ for the three models of in vitro digestion. Figure 3C-F displays the calculated percentage of intact protein from densitometry on bands. Figure 3A shows the LYS band with a Mw of around $14.3 \mathrm{kDa}$ that seems unaffected by pepsin throughout the gastric phase in the infant and early phase adult model (Figure $3 \mathrm{~A} 1, \mathrm{~A} 3$ ), which is also reflected in the densitometry analysis in Figure $3 C$. There is only a statistically significant decrease of the intensity of the band of intact LYS at 20 min of the gastric phase in the late phase adult model (Figure 3C) and a faint band of much lower Mw, 2-3 kDa, appeared (Figure $3 \mathrm{A5}$ ) corresponding to hydrolysis products. The band of intact LYS had completely disappeared after 60 min of the gastric phase in this model. The resistance of LYS to pepsin digestion agrees well with the results reported by Fu and co-workers under conditions of the gastric late phase adult model or pepsin resistance test. ${ }^{7}$ However, intact LYS could be seen in their SDS-PAGE until 60 min of the gastric phase, which contrasts with our results, where intact LYS could be seen until 30 min (Figure 3 A5). This difference might be caused by 


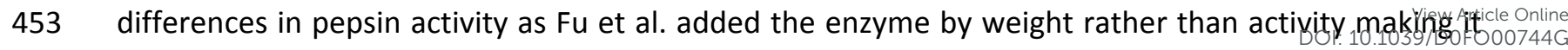

454 difficult to compare.

455 In contrast to LYS, OVA was more susceptible to pepsin digestion, at least under conditions of the 456 early and late phase adult models (Figure 3 B3, B5). The intensity of the band corresponding to intact 457 OVA ( $\mathrm{Mw} \sim 45 \mathrm{kDa}$ ) remains constant throughout the infant gastric digestion (Figure $3 \mathrm{~B} 1$ and E). In 458 the early phase adult model, the proteolysis starts to be statistically significant after 20 min of the 459 gastric phase as shown by the decrease of band intensity (Figure 3E) and appearance of protein 460 fragments of slightly lower $\mathrm{Mw}$ and much smaller hydrolysis products of Mw of 3-4 kDa (Figure 3 461 B3). A larger extent of OVA gastric digestion was found with an infant model by Dupont and co462 workers, ${ }^{6}$ which is likely due to the lower gastric $\mathrm{pH}(\mathrm{pH} 3)$ used in their study that is more optimal 463 for pepsin activity, $70 \%$ of the maximum in comparison to $10 \%$ at $\mathrm{pH} 5.3 .{ }^{34}$ This also demonstrates 464 the importance of setting a relevant $\mathrm{pH}$ because it affects the enzymatic activity. The rate of OVA 465 gastric proteolysis in an adult model was also slightly faster in their study, but the gastric extent is 466 very similar to that obtained here (ca. 20\%). In the late phase adult model (Figure 3 B5), the 467 proteolysis occurs at earlier times, $5 \mathrm{~min}$, as seen in Figure 3E, although intact OVA could still be 468 seen at $30 \mathrm{~min}$. This is in complete agreement with the results of pepsin resistance test obtained in 469 the majority of laboratories (6 out of 9) in a ring trial. ${ }^{5}$ Furthermore, the densitometry profile shown 470 in Figure 3E greatly resembles that reported by Takagi and co-workers for the pepsin resistance test 471 of OVA. ${ }^{36}$ 


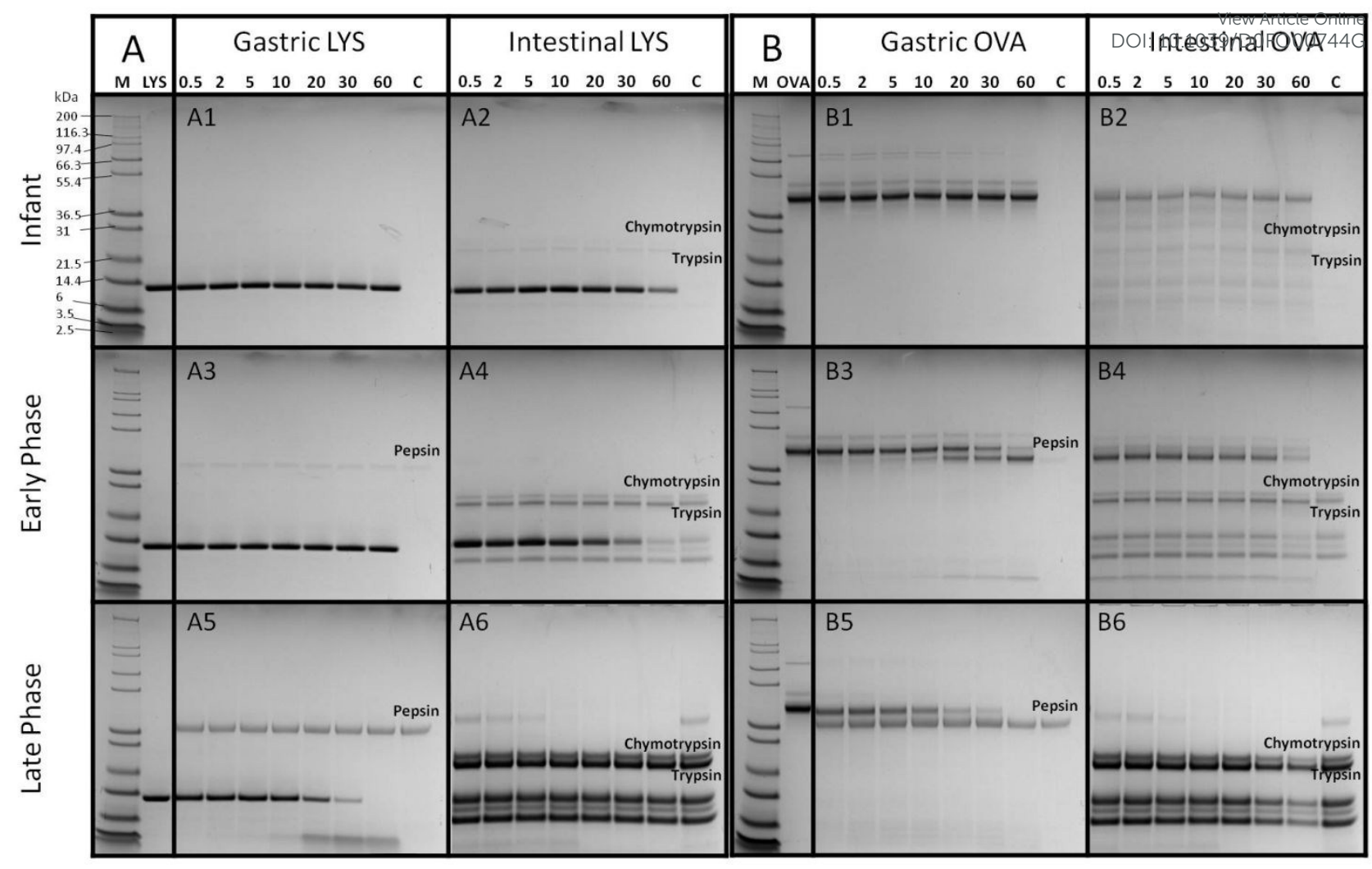

\section{C) Gastric LYS}

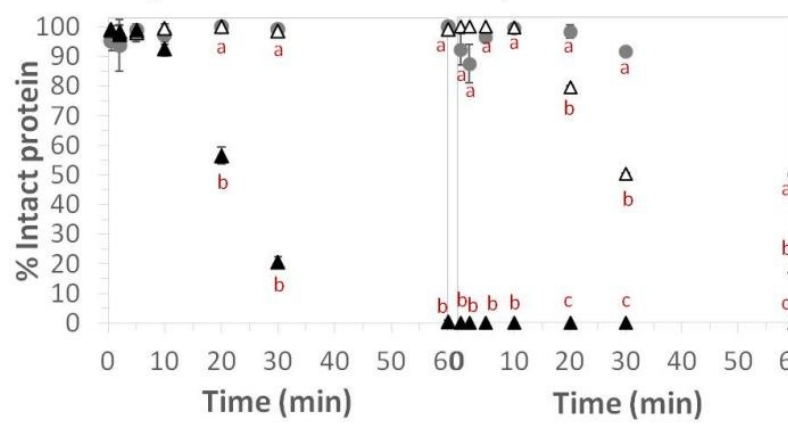

E) Gastric OVA

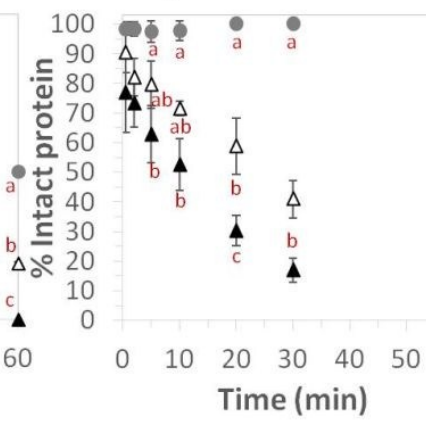

F) Intestinal OVA

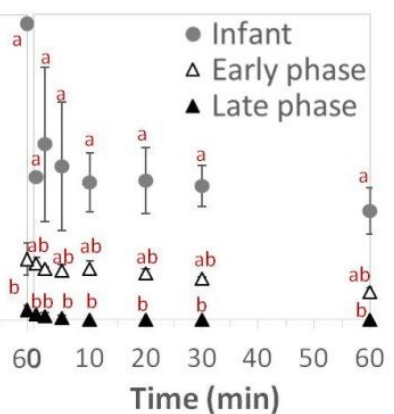

Figure 3: SDS-PAGE of the digesta of isolated LYS (A) and OVA (B) with the infant, early phase adult and late phase adult models. The numbers at the top of the lanes represent the time in min of the gastric or intestinal phase. The M lane corresponds to the Mw marker. LYS and OVA lanes are the protein blank and the $C$ lane is the control of the digestive enzymes. Percentage of intact protein $C$ ), D) LYS and E), F) OVA within the gastric or intestinal phase determined from densitometry on SDSPAGE $(n \geq 2)$. Different letters mean significant differences $(p \leq 0.05)$ between models over time. Absence of letters means no significant differences.

Different intestinal proteolysis can also be observed across models and between proteins. In general, the proteolysis was slower and reached a lower extent in the infant model, intermediate behaviour occurred in the early phase adult model, and faster and greater extent was reached in the late phase adult model (Figure 3D and 3F). Although both proteins were already hydrolysed by the end of the gastric phase in the late phase model. OVA seemed to attain the maximum extent of digestion at the beginning of the intestinal phase, regardless of the model (Figure 3F), also in terms of appearance of hydrolysis products. This contrasts with LYS kinetics of intestinal proteolysis. In 


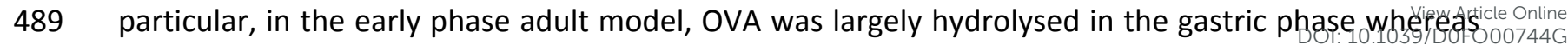
490 LYS was mostly digested in the intestinal phase (Figure 3D). This suggests that LYS is more susceptible to pancreatic enzymes while OVA is relatively resistant, which confirms previous findings on OVA intestinal stability without previous gastric phase. ${ }^{36}$ Both large protein fragments (36-45 $\mathrm{kDa})$ and low molecular weight hydrolysis products $(3 \mathrm{kDa})$ appeared across the intestinal phase of the early phase adult model (Figure $3 \mathrm{~B} 4$ ). Interestingly, the final extent of digestibility is similar for both proteins at the end of the intestinal phase within each model (Figure 3D and 3F). Specifically, approximately $40-50 \%$ of intact protein remains in the infant model, $10-20 \%$ in the early phase adult model and $0 \%$ in the late phase adult model. The varying extent of protein intestinal digestion across the three models can be ascribed not only to the different trypsin/chymotrypsin to test protein ratio, but also to the different concentrations of bile salts. It has been shown that greater bile salt concentration accelerates the rate of proteolysis for certain dietary proteins. ${ }^{37}$ The kinetics and extent of OVA intestinal proteolysis in the infant and early phase adult model agree very well with previous results. ${ }^{6}$ The different extent of proteolysis of LYS and OVA at the end of the intestinal phase for each in vitro digestion model emphasises the relevance of considering different $\mathrm{Gl}$ scenarios representative of the physiological situation in adults and infants. The fact that a protein is fully hydrolysed in the late phase adult model does not necessarily imply complete digestion with the other two models. Therefore, the current pepsin resistance test (corresponding to the gastric late phase adult model) may only be suitable for a first screening, whereby proteins that are resistant to digestion under these harsh conditions are not expected to be digested under the milder conditions of the early phase adult or infant models.

LC-MS/MS data indicate that LYS only generated 16 unique peptides during in vitro digestion in the gastric phase and 20 unique peptides in the intestinal phase in total across the three models (Table 1). These low numbers of peptides are in accordance with the high resistance of LYS to GI digestion seen by SDS-PAGE with the infant and early phase adult model, and confirm previously published results. ${ }^{8}$ It was shown in that study that the resistance of LYS to pepsin digestion is due to its rigid structure given by the four disulphide bridges and proteolysis only occurred at a highly acidic $\mathrm{pH}$ range from 1.2 to 2 , likely because of the slightly increased flexibility of LYS at this $\mathrm{pH}^{38}$ It is therefore reasonable to identify more peptides in the gastric compartment with the late phase adult model (16) than with the other two models ( 4 in the infant model and 3 in the early phase adult model) (Table 1). In addition, it has been shown that when cleaved by pepsin, LYS leads to the formation of peptides of Mw less than $4-5 \mathrm{kDa},{ }^{8}$ which are not readily detectable by the LC-MS/MS protocol used in the current study (Figure 4a). Indeed, SDS-PAGE showed the appearance of hydrolysis products of around $3.5 \mathrm{kDa}$ at 20 min of the gastric late phase adult model (Figure $3 \mathrm{A5}$ ). In the intestinal phase, LYS has been shown to precipitate in the presence of bile salts making it quite resistant to proteolysis. ${ }^{8}$ In any case, since the number of peptides coming from LYS clearly identified is rather low (Table 1), the statistical analysis of the dataset does not bring much relevant information. 


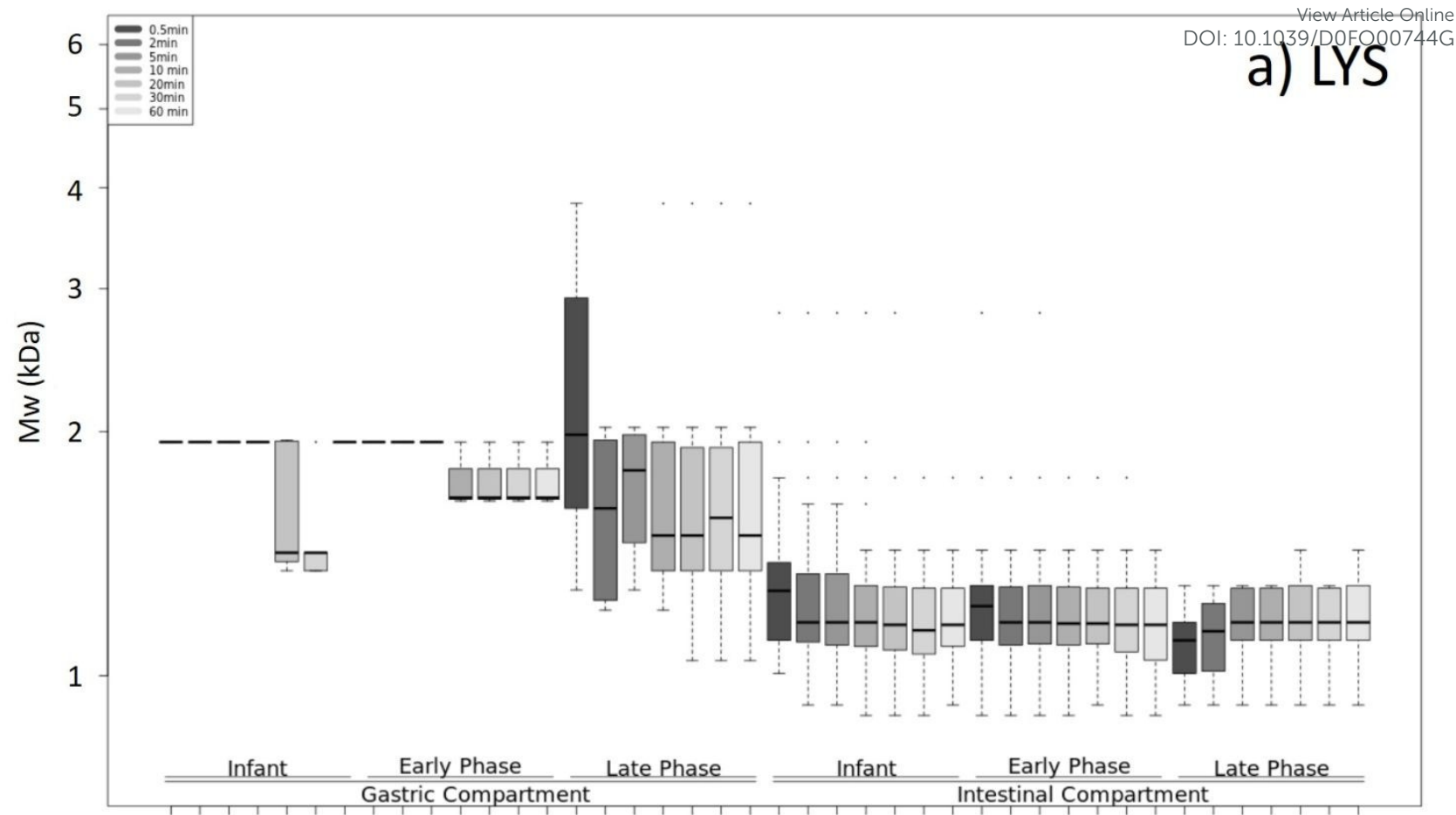

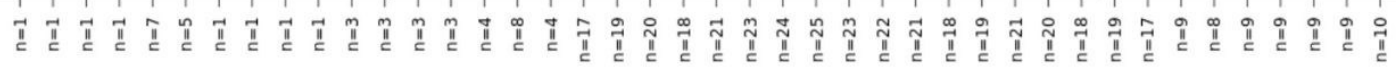

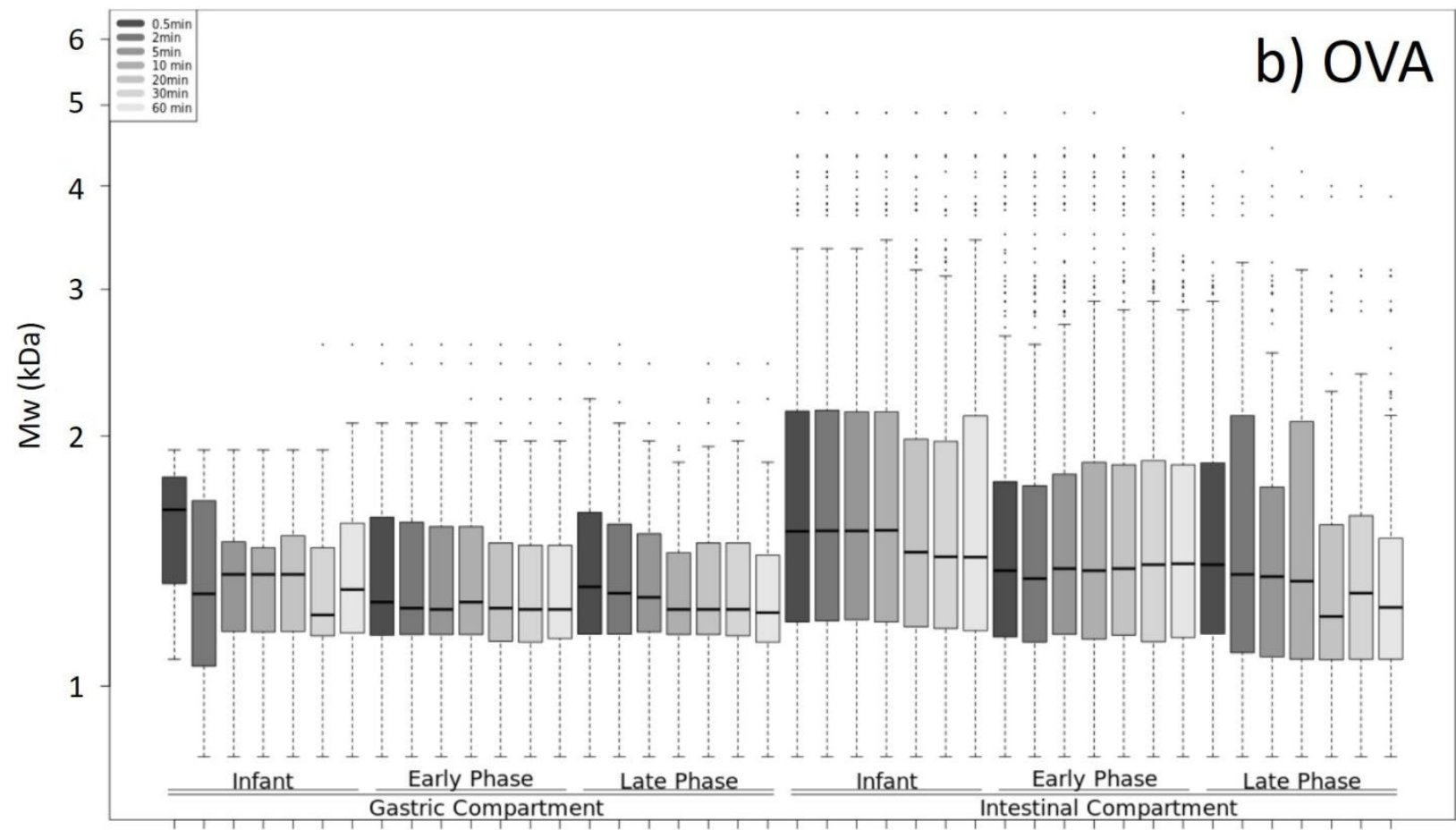

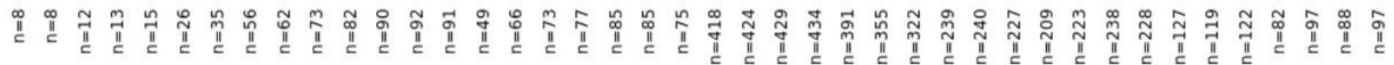

Figure 4: A box plot of peptide molecular weight from LYS (a) and OVA (b) after gastric and intestinal digestion with the three in vitro models. Numbers at the bottom are the number of unique peptide sequences identified at each time point. adult models were of higher Mw compared to peptides from the infant model (Figure 4b), although 
the trend in time of the median Mw shows values slightly higher in the infant model and sibiniarticle Online between the two adult models. This gastric behaviour follows a similar trend to that for BLG and BCS (Figure 2), confirming a more intense proteolysis in the adult models. The median Mw values of the peptides decreased on average slightly with time, regardless of the model. Peptides from OVA of much larger $\mathrm{Mw}$ were identified in the intestinal phase, which may be attributable to a larger proportion of the protein being hydrolysed by intestinal enzymes (Figure 3B). This leads to more diversity in the peptides released and resembles the behaviour found for BLG in Figure 2a, where larger peptides were indentified in the intestinal phase compared to the gastric phase. In this case, peptides of higher $\mathrm{Mw}$ were seen in the infant model, followed by the early phase and late phase adult models, which may be explained by the lower extent of proteolysis in the infant model (Figure $3 \mathrm{~B}$ and $3 \mathrm{~F}$ ). Only in the infant and late phase adult models was evolution of peptide size, median $\mathrm{Mw}$, with time observed. In summary, a total of 91 unique peptides were identified in the gastric phase after in vitro digestion of OVA and 434 in the intestinal phase across the three models (Table 1). The larger number of peptides identified in the intestinal phase as compared to the gastric phase positively correlates with a greater extent of proteolysis.

As a general trend and as for isolated milk proteins, the number of unique peptides identified in the gastric phase increases in the order infant $\leq$ early phase $\leq$ late phase for LYS and OVA and the opposite is observed in the intestinal phase (Table 1). Therefore, this confirms a positive correlation between the number of unique peptides identified in the gastric compartment and the in vitro digestibility. This is inconclusive in the intestinal stage.

\subsection{Impact of the food matrix/processing on in vitro protein digestion}

The in vitro digestion of proteins in bovine milk with the three models was first monitored with SDSPAGE and results are shown in Figure 5A, with particular focus on BLG and BCS. In this case, the lane labelled as "Milk" corresponds to the meal blank before digestion, showing the band corresponding to intact BCS within the group of bands of caseins, and BLG band at lower Mw. The whey protein $\alpha-$ lactalbumin (allergen Bos $\mathrm{d} \mathrm{4}$ ) of around $14.2 \mathrm{kDa}$ can also be seen below the BLG band, as well as MFGM proteins at higher molecular weight ( $>55 \mathrm{kDa}$ ) and bovine serum albumin (allergen Bos $\mathrm{d} 6$ ) (66.5 kDa). ${ }^{14}$ The control lane " $\mathrm{C}$ " in the intestinal phase corresponds to the digestive enzymes present in pancreatin. This complex pancreatic mixture represents a more realistic environment and was used to digest in vitro the food matrix (milk and eggs). Despite the difficulty of reading SDSPAGE at relatively large concentrations of pancreatin, i.e. in the late phase adult model, some useful information can still be inferred from the comparison with the infant and early phase adult models. The gastric digestibility profile of BLG and BCS in the whole milk matrix (Figure 5B and 5D) follows a similar trend for the three in vitro models as compared to the isolated proteins. The results from isolated proteins (lines in Figure 5B-E) are also included as a reference. Namely, BLG resisted hydrolysis throughout the gastric phase regardless of the model, whereas BCS was susceptible to pepsin digestion and its hydrolysis was instantaneous upon starting the gastric phase in the late phase adult model, whereas it was slower in the early phase adult and infant models. Although the impact of the food matrix on protein digestion is expected to be less relevant in milk because it is a liquid, the effect of thermal processing and homogenisation needs to be considered as well. It has been reported that the temperature of the pasteurisation process $\left(72^{\circ} \mathrm{C}\right)$ was not sufficient to cause any important changes in the in vitro gastric digestion of milk proteins as compared to raw milk (non-heated). ${ }^{14}$ The latter study was carried out with a semi-dynamic gastric model and comparing milk matrices, not with isolated proteins. Nevertheless, a fast comparison in Figure 5D reveals slight but significant differences, at least in the dynamics of the early phase adult model. BCS, as part of 


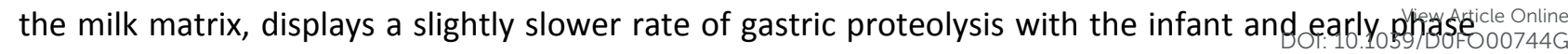
adult models as compared to the isolated BCS in water, but the final extent is similar. It is known that heating above $70{ }^{\circ} \mathrm{C}$ induces the denaturation of whey proteins, and that denatured whey proteins bind to $k$-casein, both at casein micelle surface and in serum phase. ${ }^{39}$ This complexation with the surface of casein micelles may exert a protective effect and slightly delay the hydrolysis of BCS as compared to isolated non-heated BCS in aqueous solution. Tunick and co-workers showed a slightly higher resistance of BCS to pepsinolysis in homogenised pasteurised whole milk as compared to raw milk during the first 15 min of gastric in vitro digestion, as seen by SDS-PAGE. ${ }^{12}$ SanchezRivera et al. reported a noticeable increased resistance of the casein fraction to pepsin digestion in heated skimmed milk proteins as compare to unheated sample in dynamic in vitro gastric digestion..$^{40}$ However, it must be taken into account the higher heating temperature used in the latter study $\left(90^{\circ} \mathrm{C}\right)$, the non-fat nature of the milk, and the dynamic model of the gastric phase. One could also argue that the enzyme/substrate ratio is lower in the in vitro digestion of meals than for isolated proteins due to the larger protein content. For instance, the concentration of total protein in milk is $35 \mathrm{mg} / \mathrm{mL}$ approximately as compared to $5 \mathrm{mg} / \mathrm{mL}$ in isolated protein samples. Nevertheless, the enzyme/substrate ratio should still be high enough to overcome any inhibitory effect.

On the other hand, a rapid BLG hydrolysis was observed in the intestinal phase of milk for both adult models as for isolated BLG (Figure $5 \mathrm{C}$ ). However, BLG in the milk matrix exhibits lower extent of intestinal digestion with the infant model as compared to the isolated BLG in water. The most plausible explanation is that the average gastric $\mathrm{pH}$ in the infant model (5.3) induced milk coagulation..$^{41}$ It has been reported that BLG is present in the clots of heated homogenised milk going through a dynamic gastric simulation. ${ }^{13}$ Heating causes the association of whey proteins with casein micelles and the association of non-micelle-bound whey protein and $k$-casein into complexes, which associate with the micelles at $\mathrm{pH}$ values $\leq 5.3 .{ }^{41}$ This may have protected BLG from pancreatic enzymes upon gradual intestinal digestion of the clots. Indeed, the static infant gastric model of this study would be closer to the initial stages of an adult dynamic gastric model, with more elevated $\mathrm{pH}$, due to the buffering capacity of the meal. It has been shown that the kinetics of digestion of milk proteins varies according to the in vitro digestion model applied: static versus semi-dynamic. ${ }^{14}$ The semi-dynamic model was designed to replicate some realistic behaviour found in the stomach in vivo. ${ }^{42}$ The semi-dynamic model considers not only the buffering capacity of the meal, which increases the gastric $\mathrm{pH}$ immediately after meal intake, but also the gradual acidification with the progressive secretion of the gastric fluid containing the enzymes, and the gastric emptying. Therefore, in a more realistic scenario, caseins from milk coagulate in the stomach, which affects their digestibility and delays their gastric emptying, as compared to BLG that empties throughout the gastric phase. However, this observation does not apply for UHT-treated milk. ${ }^{14}$ Thus, food processing is another factor to be taken into account. Regardless of these potential issues, Egger and co-workers compared the digestion of milk proteins in vivo and in vitro (INFOGEST consensus protocol for static digestion) and observed an agreement between the end points of the gastric and intestinal phases, respectively. ${ }^{16}$ 


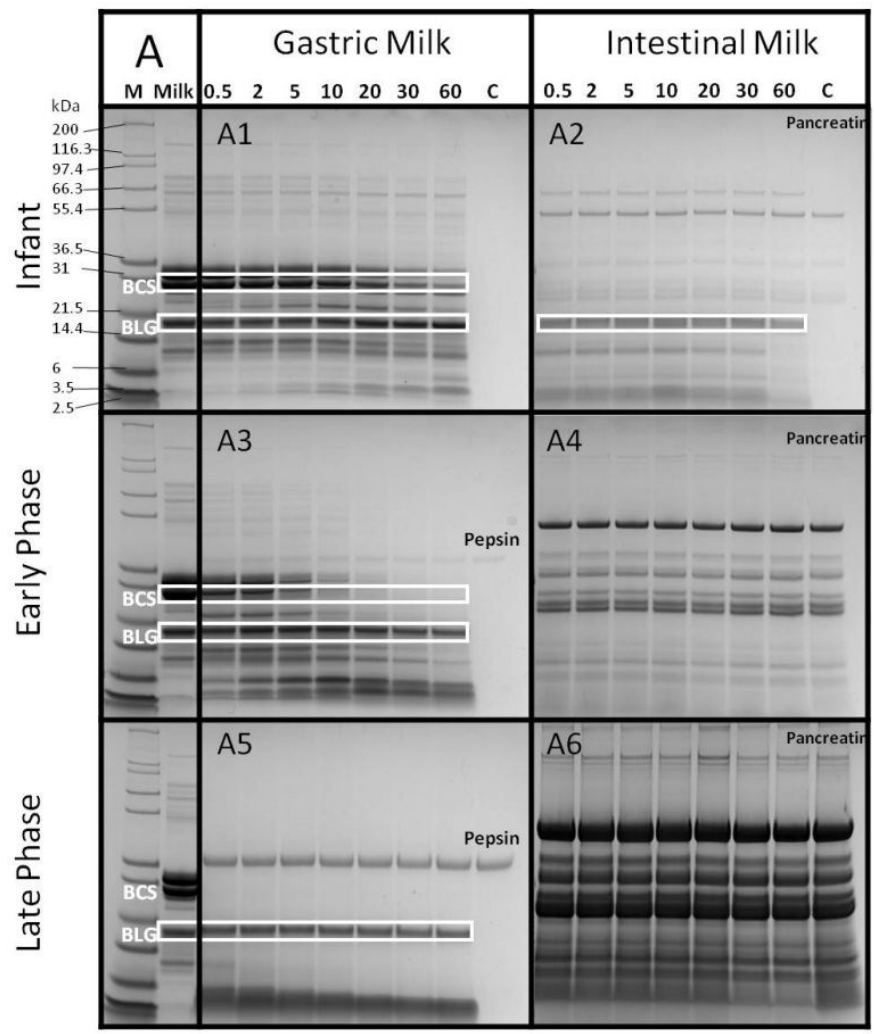
B) Gastric BLG
C) Intestinal BLG

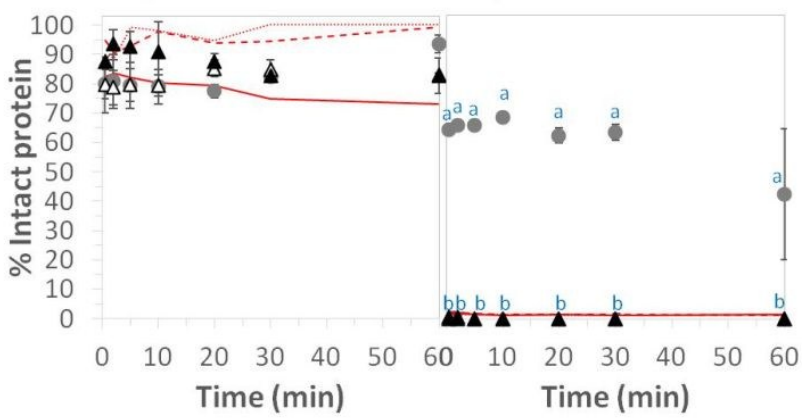

D) Gastric BCS

E) Intestinal BCS

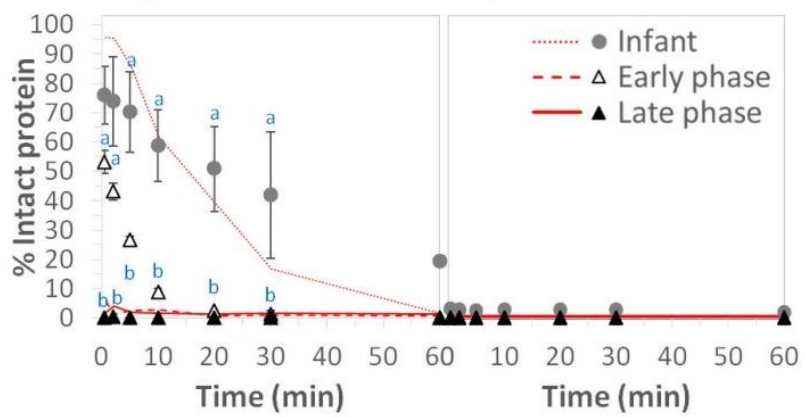

Figure 5: SDS-PAGE of the digesta of fresh whole milk (A) with the infant, early phase adult and late phase adult models. The numbers at the top of the lanes represent the time in min of the gastric or intestinal phase. The $\mathrm{M}$ lane corresponds to the Mw marker. The Milk lane is the meal blank and the C lane is the control of the digestive enzymes. Percentage of intact protein B), C) BLG and D), E) BCS within the gastric or intestinal phase of milk (symbols) determined from densitometry on SDS-PAGE $(n \geq 2)$. Different letters mean significant differences $(p \leq 0.05)$ between models over time. Absence of letters means no significant differences. Lines are results from isolated proteins in Figure 1. 
631 Figure 6A shows the proteolysis during the in vitro digestion of soft-boiled hen's egg with the three models. The lane labelled as "Egg" corresponds to the meal blank before digestion, showing the bands corresponding to OVA and LYS. Other egg white proteins can also be identified, such as ovomucins above $95 \mathrm{kDa}$, ovotransferrin (allergen Gal d 3) of around $76 \mathrm{kDa}$, and ovomucoid (allergen Gal d 1) of approximately $28 \mathrm{kDa}$, but with higher apparent Mw (around $36.5 \mathrm{kDa}$ ) due to its high degree of glycosylation. ${ }^{17}$ Egg yolk proteins can also be detected: $\alpha$-livetin (allergen Gal d 5) of around $70 \mathrm{kDa}$. In general, the GI proteolysis of LYS and OVA as part of the soft-boiled egg matrix follows a similar trend (Figure 6B-E) to the isolated proteins in aqueous solution. Namely, a lower extent of hydrolysis is seen for the infant model, intermediate extent for the early phase adult model and larger extent for the late phase adult model. Nevertheless, there were differences in the in vitro digestion of both proteins regarding the effect of the food matrix and processing, i.e. soft boiling. LYS was hydrolysed faster within the egg matrix throughout the gastric and intestinal phase regardless of the model (Figure $6 \mathrm{~B}$ and $6 \mathrm{C}$ ), although the maximum extent of hydrolysis at the beginning of the intestinal phase was similar to that attained for isolated LYS in aqueous solution at the end of the intestinal phase. Specifically, 40-50\% intact LYS remains in the infant model, $10-20 \%$ in the early phase adult model, and $0 \%$ in the late phase adult model. Martos and co-workers reported a slightly higher susceptibility of raw egg white protein to GI hydrolysis in the presence of egg yolk, although an increased amount of intact LYS was found after intestinal digestion. ${ }^{17}$ The authors attributed these results to the presence of components in the egg yolk, such as phosphatidylcholine, that partially prevents LYS precipitation in the presence of bile salts in the intestinal phase, ${ }^{8}$ and soluble LYS seemed to be resistant to proteolysis. The faster LYS digestion observed in our current study may be explained by thermal processing. Wang and co-workers reported greater egg white protein digestibility when separated from egg yolk in hard-boiled egg as compared to raw egg stored at $4{ }^{\circ} \mathrm{C} .{ }^{21}$ In addition, Liu et al. reported increased digestibility of LYS and OVA in egg white when heated at $80{ }^{\circ} \mathrm{C}$ at a wide range of $\mathrm{pH}(4-9) .{ }^{22}$ However, OVA attained a lower extent of digestion within the egg matrix during the gastric phase for both adult models (Figure 6D), although a similar extent was reached over the course of the intestinal phase regardless of the model (Figure 6E), compared to isolated OVA in aqueous solution. Heat-induced $\left(80^{\circ} \mathrm{C}\right.$ for $6 \mathrm{~h}$ ) denaturation and aggregation of isolated OVA has been shown to enhance its in vitro gastrointestinal digestion due to exposure of additional proteolytic cleavage sites that are hidden in the native state. ${ }^{19,20}$ The same was observed when heating OVA at higher temperature $\left(100^{\circ} \mathrm{C}\right.$ for 5 $\min ) .{ }^{36}$ However, the lower extent of pepsinolysis of OVA within the egg matrix in the current study as compared to non-heated isolated OVA might be caused by posttranslational modifications, such as glycosylation in the presence of reducing sugars like glucose during cooking. ${ }^{18}$ Additionally, it could be due to a limited access of the enzyme cleavage sites in the semi-solid matrix, and once the matrix structure has been broken down at the end of the gastric phase, there is no difference between the intestinal digestion of isolated OVA and within the soft-boiled egg. Martos and coworkers observed a lower extent of duodenal digestion of OVA in the whole raw egg matrix as compared to isolated OVA and attributed the effect to the presence of ovomucoid, a trypsin inhibitor that partially retains its inhibitory activity after pepsin digestion. ${ }^{17}$ We have not found significant differences in the intestinal digestion of intact OVA when in the soft-boiled egg matrix or isolated. Therefore, soft boiling the egg may have affected the inhibitory activity of ovomucoid. ${ }^{43}$ However, this inhibitory effect may only be relevant in the infant model where ovomucoid (36.5 $\mathrm{kDa}$ ) seems to resist pepsin digestion. In summary, the effect of the egg matrix and processing, i.e. soft-boiling, had an impact on the kinetics of protein hydrolysis and gastric end point, but not on the intestinal end point. 


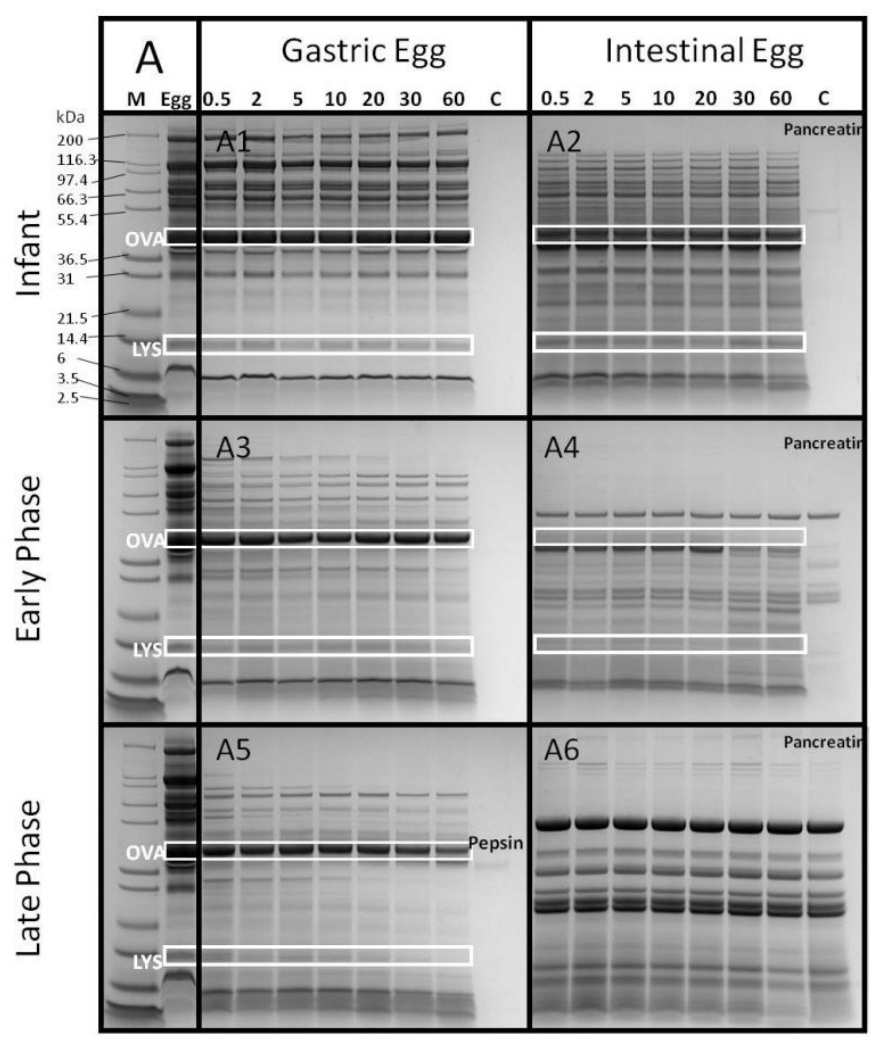

$\begin{array}{ll}\text { B) Gastric LYS } & \text { C) Intestinal LYS }\end{array}$

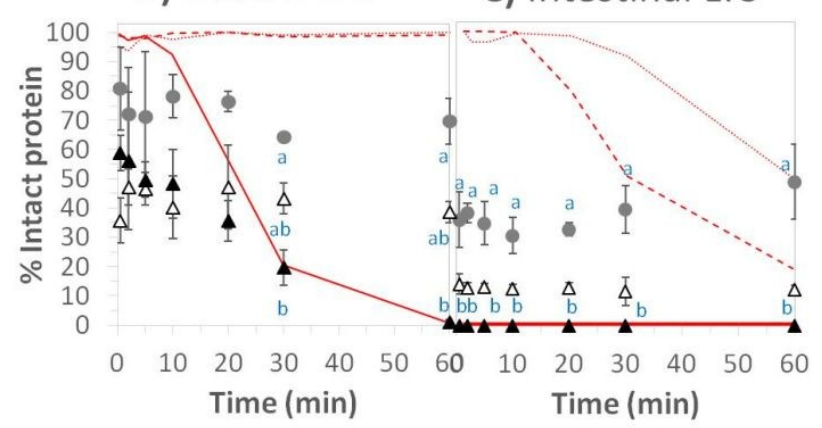

D) Gastric OVA

E) Intestinal OVA

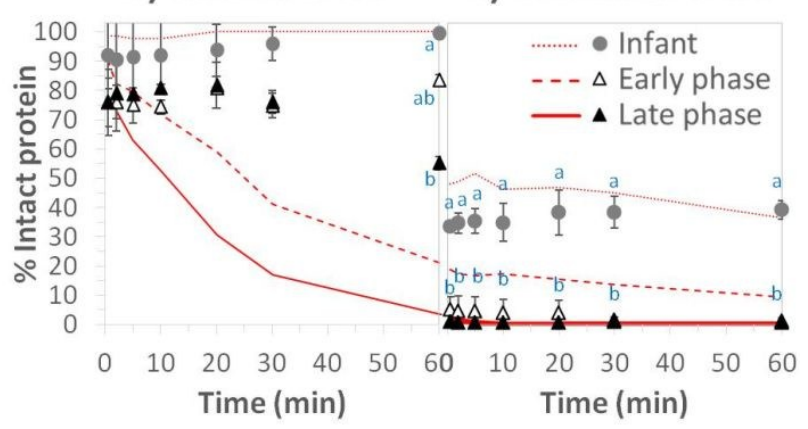

Figure 6: SDS-PAGE of the digesta of soft-boiled egg (A) with the infant, early phase adult and late phase adult models. The numbers at the top of the lanes represent the time in min of the gastric or intestinal phase. The M lane corresponds to the Mw marker. The Egg lane is the meal blank and the C lane is the control of the digestive enzymes. Percentage of intact protein B), C) LYS and D), E) OVA within the gastric or intestinal phase of egg (symbols) determined from densitometry on SDS-PAGE 
684

685

686

687

688

689

690

691

692

693

694

695

696

697

698

699

700

701

702

703

704

705

706

707

708

709

710

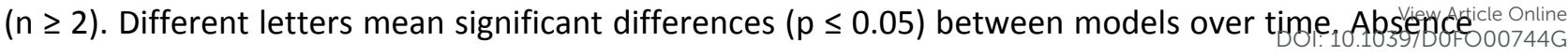
of letters means no significant differences. Lines are results from isolated proteins in Figure 3.

The densitometry analysis on SDS-PAGE to determine the digestibility of specific proteins within the food matrix might not be completely accurate since some peptides coming from the hydrolysis of higher $\mathrm{Mw}$ proteins can also correspond to the $\mathrm{Mw}$ of intact proteins. However, in terms of total protein, one can still appreciate obvious differences in the digestibility of milk and egg proteins across the three in vitro models (Figures 5A and 6A). Regarding proteolysis in milk, SDS-PAGE shows a faster disappearance of bands corresponding to MFGM proteins ( $>55 \mathrm{kDa}$ ), bovine serum albumin $(66.5 \mathrm{kDa})$ and $\alpha$-lactalbumin $(14.2 \mathrm{kDa})$ in the adult models as compared to the infant model (Figure $5 \mathrm{~A})$. This can also be generalised for the hydrolysis of other proteins in the egg matrix, such as high $\mathrm{Mw}$ ones ( $>55 \mathrm{kDa}$ ) and proteins bands at around 31 and $36.5 \mathrm{kDa}$ (Figure $6 \mathrm{~A})$.

To further assess the effect of the different simulated GI conditions on protein digestibility in the food matrix, the OPA assay was performed on digesta samples to quantify the hydrolysis of total protein and results were compared across models. Figure 7 displays the levels of free amine groups normalised per mg of initial total protein before digestion. These levels are given in units of number of moles instead of molar concentration to account for the different volumes or dilution factors in each in vitro digestion model. The values were corrected for the level of free amine groups present in the control of digestive enzymes. In general, the amount of released free amine groups increases over time as the protein hydrolysis proceeds in the gastric and the intestinal phase. ${ }^{14,22}$ Differences in kinetics and extent of total protein digestion are observed between in vitro models for both meals following the trend seen so far with SDS-PAGE. Namely, a lower extent of digestion for the infant model, intermediate values for the early phase adult model and larger extent of digestion for the late phase adult model. These results support the different extent of hydrolysis of total protein in both meals across models observed by SDS-PAGE, highlighting the importance of the relevant human conditions simulated in vitro when digesting whole food matrices. 
a) Gastric phase Milk

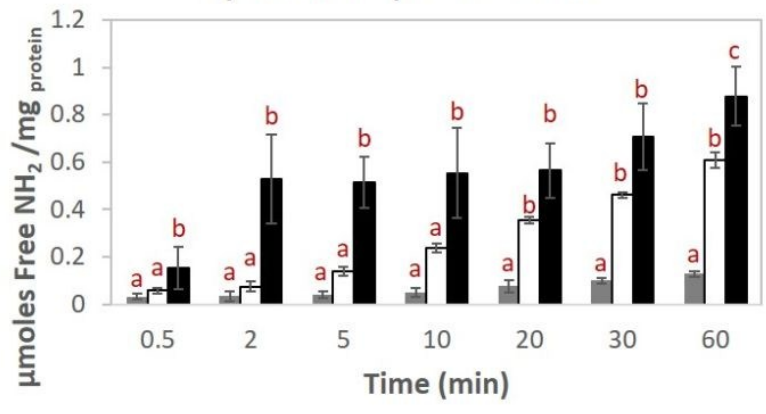

c) Gastric phase Egg

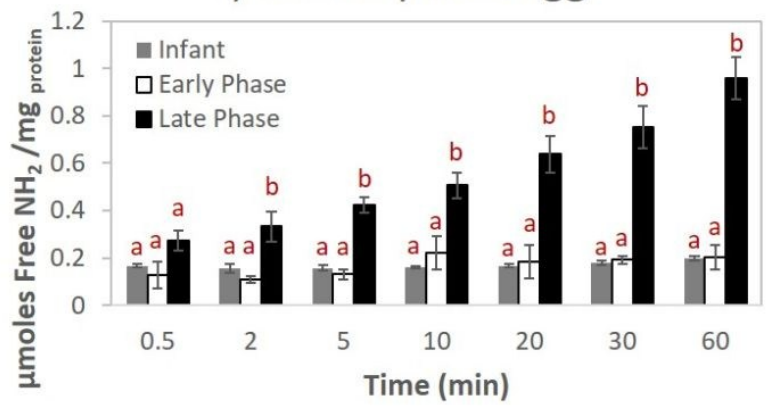

View Aticle Online

View Article Online
39/DOFO00744G

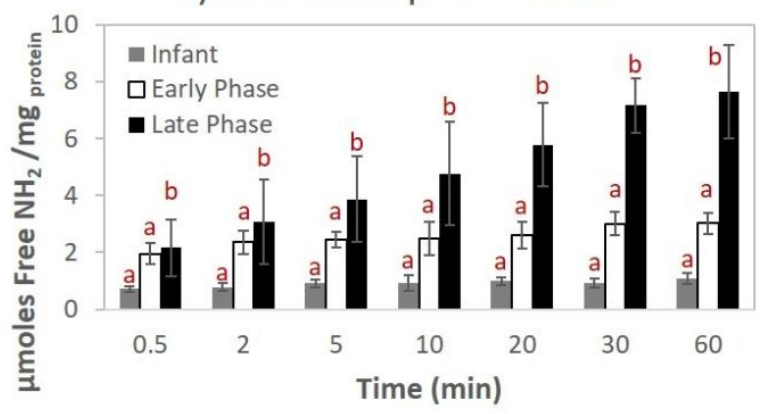

d) Intestinal phase Egg

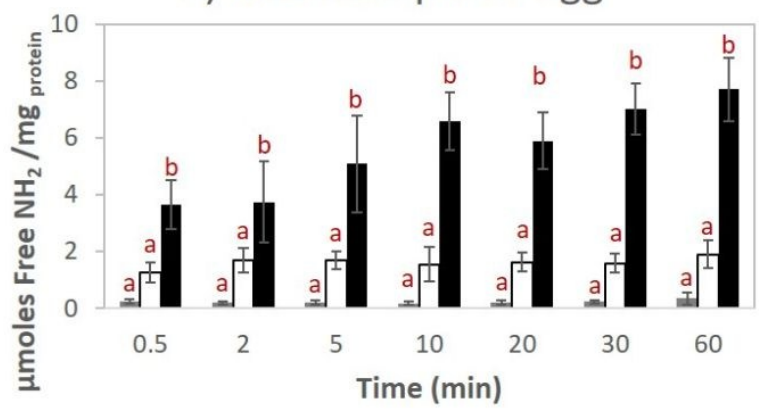

711

712

713

714

715

716

717

718

719

720

721

722

723

724

725

726

727

728

729

730

731

732

733

734

735

Figure 7: Amount of free amine groups per mass of initial total protein during gastric and intestinal digestion of bovine milk and soft-boiled hen's egg with the three models. Different letters mean significant differences ( $p \leq 0.05$ ) between models over time.

\section{Conclusions}

Considering that static models of in vitro digestion can only provide physiologically relevant results at the end points of the gastric and intestinal phases, the conclusions and recommendations in our study are elaborated in terms of the final extent of proteolysis rather than on kinetics.

An effect of the digestion scenario was seen based on densitometry analysis of intact protein. Differences were seen in the final extent of gastric and intestinal digestion for isolated proteins and within the food matrix across the three models of in vitro digestion. In this regard, egg proteins LYS and OVA either isolated or as part of the egg matrix showed lower, intermediate and larger extent of gastric and intestinal proteolysis for the infant, early phase and late phase adult model, respectively. Regarding milk proteins BLG and BCS, only BLG showed lower extent of intestinal proteolysis as part of the milk matrix in the infant model. More importantly, the total protein digestion in the milk and egg matrices, quantified by the OPA assay method, followed the trend above for LYS and OVA.

When considering the same in vitro digestion model, the food matrix/processing affected the final extent of proteolysis (gastric or intestinal). BLG was digested to a lower extent in the intestinal phase as part of the milk matrix in the infant model. LYS was digested in the gastric phase to a larger extent with the infant and early phase adult model in the egg matrix, whereas the opposite was observed for OVA with the two adult models. Therefore, the interaction of proteins with other components in the food matrix and thermal processing matter even if this is in a liquid/semi-liquid form, which all have an impact on the final extent of proteolysis. Future investigations on the assessment of protein digestibility should consider not only the comparison of different human relevant GI conditions, but 


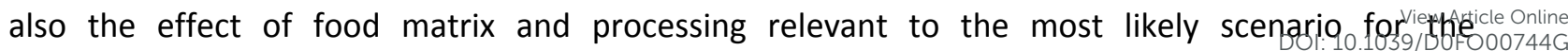
consumption of the protein under investigation.

The presence of intact protein throughout the intestinal phase, such as BLG, LYS and OVA as part of the food matrix, may be particularly relevant in infants. Their immature gut is underdeveloped and allows the absorption of appreciable quantities of intact proteins or large peptide fragments, e.g. milk proteins, yet not in nutritionally significant amount but enough to be detected in the circulating blood (4-5 orders of magnitude lower than the oral dose). ${ }^{44,45}$ In addition, peptides larger than 9 amino acids were present throughout the intestinal phase for all isolated proteins regardless of the digestion model. This increases the possibility that potential immunoactive peptides encounter the immune system through the intestinal route. Work correlating persistent peptide sequences from digesta with binding epitopes positions is still in progress to elucidate differences across in vitro models for improved risk assessment on allergenicity. Further work will also be needed to assess whether this is still the case if brush border enzymes and absorption are included as part of the analysis. In any case, more targeted research will be needed to link these results to immunological outcomes.

\section{Acknowledgements}

Authors thank the financial support from the European Food Safety Authority and the School of Food Science and Nutrition of the University of Leeds. K.R. would also like to thank the financial support from Erasmus Plus Programme. Very helpful discussion with EFSA is also gratefully acknowledged.

\section{Conflicts of interest}

There are no conflicts of interest to declare.

\section{References}

1. K. L. Bogh and C. B. Madsen, Food Allergens: Is There A Correlation between Stability to Digestion and Allergenicity?, Crit. Rev. Food Sci., 2016, 56, 1545-1567.

2. EFSA GMO Panel, Scientific Opinion on Guidance for risk assessment of food and feed from genetically modified plants, Efsa J., 2011, 9, 2150.

3. H. Naegeli, A. N. Birch, J. Casacuberta, A. De Schrijver, M. A. Gralak, P. Guerche, H. Jones, B. Manachini, A. Messean, E. E. Nielsen, F. Nogue, C. Robaglia, N. Rostoks, J. Sweet, C. Tebbe, F. Visioli, J. M. Wal, P. Eigenmann, M. Epstein, K. Hoffmann-Sommergruber, F. Koning, M. Lovik, C. Mills, F. J. Moreno, H. van Loveren, R. Selb, A. F. Dumont and EFSA GMO Panel, Guidance on allergenicity assessment of genetically modified plants, Efsa J., 2017, 15, 48624911.

4. J. D. Astwood, J. N. Leach and R. L. Fuchs, Stability of food allergens to digestion in vitro, Nat. Biotechnol., 1996, 14, 1269-1273.

5. K. Thomas, M. Aalbers, G. A. Bannon, M. Bartels, R. J. Dearman, D. J. Esdaile, T. J. Fu, C. M. Glatt, N. Hadfield, C. Hatzos, S. L. Hefle, J. R. Heylings, R. E. Goodman, B. Henry, C. Herouet, M. Holsapple, G. S. Ladics, T. D. Landry, S. C. MacIntosh, E. A. Rice, L. S. Privalle, H. Y. Steiner, R. Teshima, R. van Ree, M. Woolhiser and J. Zawodny, A multi-laboratory evaluation of a 
common in vitro pepsin digestion assay protocol used in assessing the safety of novel View Article Online proteins, Regul. Toxicol. Pharm., 2004, 39, 87-98.

6. D. Dupont, G. Mandalari, D. Molle, J. Jardin, J. Leonil, R. M. Faulks, M. S. J. Wickham, E. N. C. Mills and A. R. Mackie, Comparative resistance of food proteins to adult and infant in vitro digestion models, Mol. Nutr. Food Res., 2010, 54, 767-780.

7. T. T. Fu, U. R. Abbott and C. Hatzos, Digestibility of food allergens and nonallergenic proteins in simulated gastric fluid and simulated intestinal fluid - A comparative study, J. Agric. Food Chem., 2002, 50, 7154-7160.

8. R. Jimenez-Saiz, G. Martos, W. Carrillo, R. Lopez-Fandino and E. Molina, Susceptibility of lysozyme to in-vitro digestion and immunoreactivity of its digests, Food Chem., 2011, 127, 1719-1726.

9. E. N. C. Mills, A. I. Sancho, N. M. Rigby, J. A. Jenkins and A. R. Mackie, Impact of food processing on the structural and allergenic properties of food allergens, Mol. Nutr. Food Res., 2009, 53, 963-969.

10. K. Thomas, C. Herouet-Guicheney, G. Ladics, G. Bannon, A. Cockburn, R. Crevel, J. Fitzpatrick, C. Mills, L. Privalle and S. Vieths, Evaluating the effect of food processing on the potential human allergenicity of novel proteins: International workshop report, Food Chem. Toxicol., 2007, 45, 1116-1122.

11. S. J. E. Lee and J. W. Sherbon, Chemical changes in bovine milk fat globule membrane caused by heat treatment and homogenization of whole milk, J. Dairy Res., 2002, 69, 555-567.

12. M. H. Tunick, D. X. X. Ren, D. L. Van Hekken, L. Bonnaillie, M. Paul, R. Kwoczak and P. M. Tomasula, Effect of heat and homogenization on in vitro digestion of milk, J. Dairy Sci., 2016, 99, 4124-4139.

13. A. Q. Ye, J. Cui, D. Dalgleish and H. Singh, Effect of homogenization and heat treatment on the behavior of protein and fat globules during gastric digestion of milk, J. Dairy Sci., 2017, 100, 36-47.

14. A. I. Mulet-Cabero, A. R. Mackie, P. J. Wilde, M. A. Fenelon and A. Brodkorb, Structural mechanism and kinetics of in vitro gastric digestion are affected by process-induced changes in bovine milk, Food Hydrocolloid, 2019, 86, 172-183.

15. O. Menard, C. Bourlieu, S. C. De Oliveira, N. Dellarosa, L. Laghi, F. Carriere, F. Capozzi, D. Dupont and A. Deglaire, A first step towards a consensus static in vitro model for simulating full-term infant digestion, Food Chem., 2018, 240, 338-345.

16. L. Egger, O. Menard, C. Baumann, D. Duerr, P. Schlegel, P. Stoll, G. Vergeres, D. Dupont and R. Portmann, Digestion of milk proteins: Comparing static and dynamic in vitro digestion systems with in vivo data, Food Res. Int., 2019, 118, 32-39.

17. G. Martos, R. Lopez-Fandino and E. Molina, Immunoreactivity of hen egg allergens: Influence on in vitro gastrointestinal digestion of the presence of other egg white proteins and of egg yolk, Food Chem., 2013, 136, 775-781.

18. R. Jimenez-Saiz, J. Belloque, E. Molina and R. Lopez-Fandino, Human Immunoglobulin E (IgE) Binding to Heated and Glycated Ovalbumin and Ovomucoid before and after in Vitro Digestion, J. Agric. Food Chem., 2011, 59, 10044-10051.

19. K. Nyemb, C. Guerin-Dubiard, D. Dupont, J. Jardin, S. M. Rutherfurd and F. Nau, The extent of ovalbumin in vitro digestion and the nature of generated peptides are modulated by the morphology of protein aggregates, Food Chem., 2014, 157, 429-438.

20. M. Claude, R. Lupi, G. Picariello, M. Drouet, C. Larre, S. Denery-Papini and C. Brossard, Digestion differently affects the ability of native and thermally aggregated ovalbumin to trigger basophil activation, Food Res. Int., 2019, 118, 108-114.

21. X. F. Wang, N. Qiu and Y. P. Liu, Effect of Different Heat Treatments on In Vitro Digestion of Egg White Proteins and Identification of Bioactive Peptides in Digested Products, J. Food Sci., 2018, 83, 1140-1148. 
22. Y. F. Liu, I. Oey, P. Bremer, P. Silcock and A. Carne, Proteolytic pattern, protein breakdowiviw Article Online and peptide production of ovomucin-depleted egg white processed with heat or pulsed electric fields at different pH, Food Res. Int., 2018, 108, 465-474.

23. V. Lechevalier, C. Guerin-Dubiard, M. Anton, V. Beaumal, E. D. Briand, A. Gillard, Y. Le Gouar, N. Musikaphun, G. Tanguy, M. Pasco, D. Dupont and F. Nau, Pasteurisation of liquid whole egg: Optimal heat treatments in relation to its functional, nutritional and allergenic properties, J. Food Eng., 2017, 195, 137-149.

24. K. Verhoeckx, K. L. Bogh, D. Dupont, L. Egger, G. Gadermaier, C. Larre, A. Mackie, O. Menard, K. Adel-Patient, G. Picariello, R. Portmann, J. Smit, P. Turner, E. Untersmayr and M. M. Epstein, The relevance of a digestibility evaluation in the allergenicity risk assessment of novel proteins. Opinion of a joint initiative of COST action ImPARAS and COST action INFOGEST, Food Chem. Toxicol., 2019, 129, 405-423.

25. N. E. Harwood and F. D. Batista, Early Events in B Cell Activation, Annu. Rev. Immunol., 2010, 28, 185-210.

26. M. W. Handlogten, T. Kiziltepe, A. P. Serezani, M. H. Kaplan and B. Bilgicer, Inhibition of weak-affinity epitope-IgE interactions prevents mast cell degranulation, Nat. Chem. Biol., 2013, 9, 789-795.

27. T. Croguennec, F. Nau, S. Pezennec and G. Brule, Simple rapid procedure for preparation of large quantities of ovalbumin, J. Agric. Food Chem., 2000, 48, 4883-4889.

28. M. Minekus, M. Alminger, P. Alvito, S. Ballance, T. Bohn, C. Bourlieu, F. Carriere, R. Boutrou, M. Corredig, D. Dupont, C. Dufour, L. Egger, M. Golding, S. Karakaya, B. Kirkhus, S. Le Feunteun, U. Lesmes, A. Macierzanka, A. Mackie, S. Marze, D. J. McClements, O. Menard, I. Recio, C. N. Santos, R. P. Singh, G. E. Vegarud, M. S. J. Wickham, W. Weitschies and A. Brodkorb, A standardised static in vitro digestion method suitable for food - an international consensus, Food Funct., 2014, 5, 1113-1124.

29. S. S. Rossi, J. L. Converse and A. F. Hofmann, High-Pressure Liquid-Chromatographic Analysis of Conjugated Bile-Acids in Human Bile - Simultaneous Resolution of Sulfated and Unsulfated Lithocholyl Amidates and the Common Conjugated Bile-Acids, J. Lipid Res., 1987, 28, 589595.

30. A. Brodkorb, L. Egger, M. Alminger, P. Alvito, R. Assuncao, S. Ballance, T. Bohn, C. BourlieuLacanal, R. Boutrou, F. Carriere, A. Clemente, M. Corredig, D. Dupont, C. Dufour, C. Edwards, M. Golding, S. Karakaya, B. Kirkhus, S. Le Feunteun, U. Lesmes, A. Macierzanka, A. R. Mackie, C. Martins, S. Marze, D. J. McClements, O. Menard, M. Minekus, R. Portmann, C. N. Santos, I. Souchon, R. P. Singh, G. E. Vegarud, M. S. J. Wickham, W. Weitschies and I. Recio, INFOGEST static in vitro simulation of gastrointestinal food digestion, Nat. Protoc., 2019, 14, 991-1014.

31. F. C. Church, H. E. Swaisgood, D. H. Porter and G. L. Catignani, Spectrophotometric Assay Using Ortho-Phthaldialdehyde for Determination of Proteolysis in Milk and Isolated MilkProteins, J. Dairy Sci., 1983, 66, 1219-1227.

32. L. Egger, O. Menard, C. Delgado-Andrade, P. Alvito, R. Assuncao, S. Balance, R. Barbera, A. Brodkorb, T. Cattenoz, A. Clemente, I. Comi, D. Dupont, G. Garcia-Llatas, M. J. Lagarda, S. Le Feunteun, L. JanssenDuijghuijsen, S. Karakaya, U. Lesmes, A. R. Mackie, C. Martins, A. Meynier, B. Miralles, B. S. Murray, A. Pihlanto, G. Picariello, C. N. Santos, S. Simsek, I. Recio, N. Rigby, L. E. Rioux, H. Stoffers, A. Tavares, L. Tavares, S. Turgeon, E. K. Ulleberg, G. E. Vegarud, G. Vergeres and R. Portmann, The harmonized INFOGEST in vitro digestion method: From knowledge to action, Food Res. Int., 2016, 88, 217-225.

33. I. M. Reddy, N. K. D. Kella and J. E. Kinsella, Structural and Conformational Basis of the Resistance of Beta-Lactoglobulin to Peptic and Chymotryptic Digestion, J. Agric. Food Chem., 1988, 36, 737-741.

34. D. W. Piper and B. H. Fenton, PH Stability and Activity Curves of Pepsin with Special Reference to Their Clinical Importance, Gut, 1965, 6, 506-508. 
35. G. Mandalari, A. M. Mackie, N. M. Rigby, M. S. J. Wickham and E. N. C. Mills, Physiologiçäjpw Article Online phosphatidylcholine protects bovine beta-lactoglobulin from simulated gastrointestinal proteolysis, Mol. Nutr. Food Res., 2009, 53, S131-S139.

36. K. Takagi, R. Teshima, H. Okunuki and J. Sawada, Comparative study of in vitro digestibility of food proteins and effect of preheating on the digestion, Biol. Pharm. Bull., 2003, 26, 969973.

37. J. Gass, H. Vora, A. F. Hofmann, G. M. Gray and C. Khosla, Enhancement of dietary protein digestion by conjugated bile acids, Gastroenterology, 2007, 133, 16-23.

38. P. Polverino de Laureto, E. Frare, R. Gottardo, H. Van Dael and A. Fontana, Partly folded states of members of the lysozyme/lactalbumin superfamily: A comparative study by circular dichroism spectroscopy and limited proteolysis, Protein Sci., 2002, 11, 2932-2946.

39. S. G. Anema, S. K. Lee and H. Klostermeyer, Rennet-Induced Aggregation of Heated pHAdjusted Skim Milk, J. Agric. Food Chem., 2011, 59, 8413-8422.

40. L. Sanchez-Rivera, O. Menard, I. Recio and D. Dupont, Peptide mapping during dynamic gastric digestion of heated and unheated skimmed milk powder, Food Res. Int., 2015, 77, 132-139.

41. L. Donato, M. Alexander and D. G. Dalgleish, Acid gelation in heated and unheated milks: Interactions between serum protein complexes and the surfaces of casein micelles, J. Agric. Food Chem., 2007, 55, 4160-4168.

42. A. R. Mackie, H. Rafiee, P. Malcolm, L. Salt and G. van Aken, Specific food structures supress appetite through reduced gastric emptying rate, Am. J. Physiol.-Gastr. L., 2013, 304, G1038G1043.

43. I. Van der Plancken, M. Van Remoortere, A. Van Loey and M. E. Hendrickx, Trypsin inhibition activity of heat-denatured ovomucoid: A kinetic study, Biotechnol. Progr., 2004, 20, 82-86.

44. C. Andersson and I. Jakobsson, Human alpha-lactalbumin in infant serum has the same molecular size as the protein purified from human milk, Acta Paediatr. Scand., 1989, 78, 629-630.

45. M. Kuitunen, E. Savilahti and A. Sarnesto, Human alpha-lactalbumin and bovine betalactoglobulin absorption in infants, Allergy, 1994, 49, 354-360. 


\section{Table of Contents Entry}

Dairy and egg proteins either isolated or within the food matrix were subjected to different static in vitro digestion models (infant, fed and fasted adult). Proteolysis differed across models and regarding the effect of the matrix/processing.
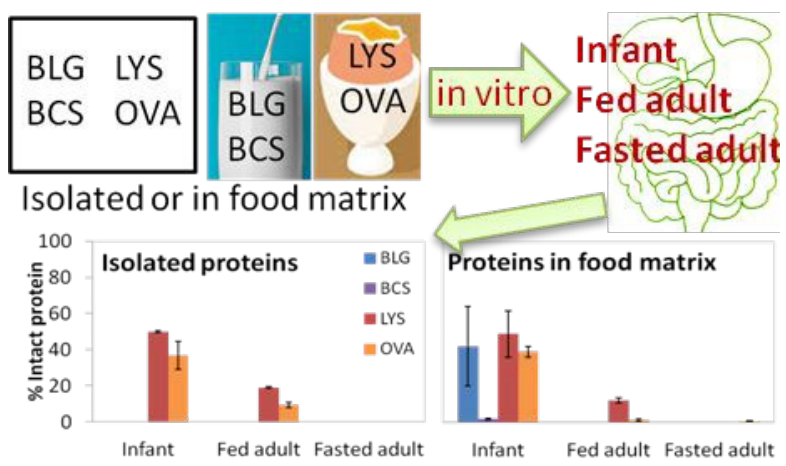